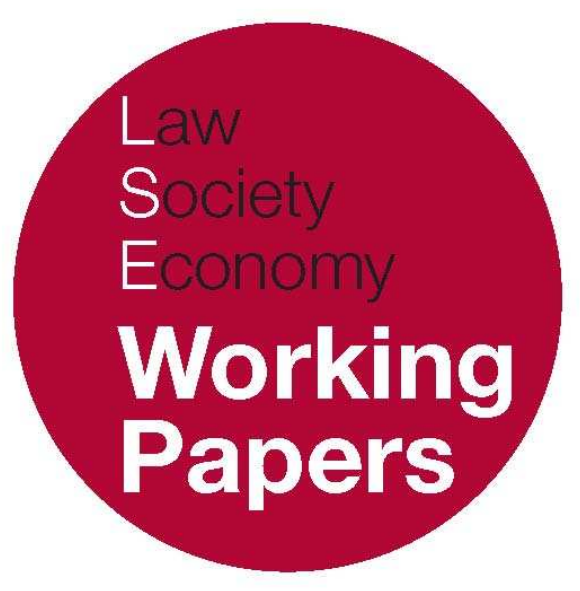

\title{
The Open Architecture of \\ European Human Rights Law
}

\author{
Nico Krisch
}

LSE Law, Society and Economy Working Papers 11/2007

London School of Economics and Political Science

Law Department

\begin{abstract}
This paper can be downloaded without charge from LSE Law, Society and Economy Working Papers at: www.lse.ac.uk/collections/law/wps/wps.htm and the Social Sciences Research Network electronic library at: http://ssrn.com/abstract=1018991.

(C) Nico Krisch. Users may download and/or print one copy to facilitate their private study or for non-commercial research. Users may not engage in further distribution of this material or use it for any profit-making activities or any other form of commercial gain.
\end{abstract}




\title{
The Open Architecture of European Human Rights Law
}

\author{
Nico Krisch ${ }^{*}$
}

\begin{abstract}
The evolution of the European human rights regime is often described in constitutionalist terms: as the move towards an integrated order with the European Convention of Human Rights as its "constitutional instrument" at the top. In this article, I seek to show that this description is misguided and that the regime is better regarded as pluralist - as characterised by a heterarchical relationship between its constituent parts that is ultimately defined politically and not legally. The emergence and workings of this pluralist order are traced through the interaction of the European Court of Human Rights with domestic courts in Spain, France, the European Union and the United Kingdom. All these cases not only show conflicts over questions of ultimate supremacy but also significant convergence and harmony in day-to-day practice. I begin to identify factors that have led to this convergence and conclude that central characteristics of pluralism - incrementalism and the openness of ultimate authority - seem to have contributed to the generally smooth evolution of the European human rights regime in a significant way. This finding suggests a broader appeal of pluralist models as alternatives to constitutionalism in the construction of postnational authority and law.
\end{abstract}

\section{INTRODUCTION}

When in October 2004 the German Constitutional Court, in its Görgülü judgment, signalled limits to its loyalty to the European Court of Human Rights (ECtHR) ${ }^{1}$, it provoked an outcry not only among scholarly commentators but also in the press and led Strasbourg judges to drop their typical reserve and voice their frustration

\footnotetext{
* Law Department, London School of Economics and Political Science, n.krisch@lse.ac.uk. A previous version of this paper was presented at faculty seminars at the LSE Law Department and at Princeton University's Woodrow Wilson School of Public and International Affairs, and I am grateful to the participants in these seminars as well as Aida Torres Perez, Alejandro Saiz Arnaiz, Carol Harlow, Cathryn Costello, Christian Walter, Christoph Möllers, Jochen Frowein, Julia Black, Marisa Iglesias, Martin Loughlin, Neus Torbisco Casals, Tom Poole and Wibren van der Burg for comments and discussion. The final version of this paper has appeared in the Modern Law Review 71 (2008) 183-216.

1 Bundesverfassungsgericht, Judgment of 14 October 2004, 2 BvR 1481/04, Entscheidungen des Bundesverfassungsgerichts 111, 307. An English translation is available at http://www.bverfg.de/ entscheidungen/rs20041014_2bvr148104en.html.
} 
in public. The president of the ECtHR and the German judge on the Court expressed serious concerns about the ramifications of the German judgment, prompting a vigorous reply by the Constitutional Court's president, all in prominent places in the German press. ${ }^{2}$ What the Constitutional Court had done was to hold that domestic courts could (and should) disregard Strasbourg judgments insofar as they are incompatible with central elements of the domestic legal order, legislative intent, or constitutional provisions. ${ }^{3}$

This position would be unsurprising if it concerned the place of other international agreements in German law, so the strength of the reaction to it must stem from features peculiar to the European human rights regime. It can in part be explained by the force of the narrative the German judgment upsets. That narrative had, for several decades, been one of constant progress: the ECtHR had largely shed its origins as an international tribunal and begun to resemble a supranational constitutional court, with an ever stronger anchoring in the domestic legal orders of member states and general acceptance of its authority as the ultimate arbiter of human rights disputes in Europe. In this vein, the story of the Strasbourg Court had come to be seen as part of the "constitutionalisation" of Europe: the successful implementation of a constitutional model of politics, in which the law lays down the ground rules of political life and enforces them through effective judicial bodies. ${ }^{4}$ The European Convention of Human Rights (ECHR), so it seemed, had become such a constitutional instrument, and the ECtHR was happy to reinforce that vision in its jurisprudence. ${ }^{5}$

As attractive as that narrative might be, reality has always been closer to Görgülï. There is no doubt that the ECtHR has, over the almost fifty years of its existence, gained remarkable authority; that its judgments enjoy high rates of

\footnotetext{
2 See 'Im Ausland mißverständlich', Frankfurter Allgemeine Zeitung, 23 October 2004, 5; 'Welches Gericht hat das letzte Wort?', Frankfurter Allgemeine Zeitung, 10 December 2004, 4; and the interviews with the then president of the ECtHR, Luzius Wildhaber, 'Das tut mir weh', Der Spiegel 47/2004, 15 November 2004, 50; and with the president of the German constitutional court, Hans-Jürgen Papier, 'Straßburg ist kein oberstes Rechtsmittelgericht', Frankfurter Allgemeine Zeitung, 9 December 2004, 5. The strong resonance in the German press is reflected in editorials by Reinhard Müller, 'Das letzte Wort', Frankfurter Allgemeine Zeitung, 23 October 2004, 1; and Heribert Prantl, 'Juristisches Röhren', Süddeutsche Zeitung, 20 October 2004, 4.

${ }^{3}$ For a short summary and comment on the decision, see F. Hoffmeister 'Germany: Status of European Convention on Human Rights in Domestic Law' (2006) 4 International Journal of Constitutional Law 722.

${ }^{4}$ See, e.g., C. Walter, 'Die Europäische Menschenrechtskonvention als Konstitutionalisierungsprozeß' (1999) 59 Zeitschrift für ausländisches öffentliches Recht und Völkerrecht 961; F. Hoffmeister, 'Die Europäische Menschenrechtskonvention als Grundrechtsverfassung und ihre Bedeutung in Deutschland' (2001) 40 Der Staat 349; E. de Wet, 'The Emergence of International and Regional Value Systems as a Manifestation of the Emerging International Constitutional Order' (2006) 19 Leiden Journal of International Law 611; see also the discussion in J.-F. Flauss, 'La Cour européenne des droits de l'homme est-elle une Cour constitutionnelle?' (1998) 36 Revue francaise de droit constitutionnel 711. Related ideas are voiced, for example, by J.A. Frowein, 'The European Convention on Human Rights as the Public Order of Europe', Collected Courses of the Academy of European Law, vol. 1:2 (Dordrecht, Boston: Martinus Nijhoff, 1992) 267358; S. Greer, The European Convention on Human Rights: Achievements, Problems and Prospects (Cambridge: Cambridge University Press, 2006) 165-189 (the ECtHR as a court with a 'constitutional mission').

${ }^{5}$ ECtHR, Judgment of 23 March 1995, Loizidou v Turkey (preliminary objections), at [75]; Judgment of 30 June 2005, Bosphorus Hava Yollar Turizm v Ireland, at [156] (the Convention as a 'constitutional instrument of European public order').
} 
compliance; and that they are now regularly cited by national courts in many, perhaps most member states. ${ }^{6}$ Yet this ever closer linkage between the national and European levels of human rights protection has been accompanied by reservations in many national legal systems, and in remarkably similar terms. As a result, it is no longer useful to see domestic and European human rights law, in the classical domestic/international dichotomy, as different legal orders; but they also do not form an integrated whole, neatly organised according to rules of hierarchy and a clear distribution of tasks.

The order we see emerging instead is, I argue, a "pluralist" one: one in which the relationships of the constituent parts are governed not by legal rules but primarily by politics, often judicial politics; where we find heterarchy, not hierarchy. ${ }^{7}$ In a pluralist order, we do not find a common set of norms at the top (a Grundnorm or rule of recognition) that would allow to resolve conflicts or would at least be the framework in which to argue about conflicts; nor do we find an agreed ultimate authority to decide on such conflicts. Instead, we find different norms and actors competing for ultimate authority; and since they lack a common legal frame of reference, they compete, to a large extent, through politics rather than legal argument. ${ }^{8}$ This contrasts with a "constitutionalist" model in which the order as a whole is subject to a unified set of norms governing the political system - a "constitution", whether written or not - in reference to which disputes about authority are decided. ${ }^{9}$ This does not mean there could not be different interpretations of those norms by different actors - in classical, domestic constitutional orders such different interpretations are frequent - but at least the norms on which the argument centres are shared and unity constitutes a common regulative ideal. ${ }^{10}$

Such a constitutionalist model is attractive for a host of reasons: mainly because it seems to be the final step in establishing the rule of law by taming politics and subjecting it to a more impartial, higher law; and because the common set of norms is an important tool for realising democratic self-government in that

\footnotetext{
${ }^{6}$ For a comparative study, see R. Blackburn \& J. Polakiewicz (eds.), Fundamental Rights in Europe: The European Convention on Human Rights and its Member States, 1950-2000 (Oxford: Oxford University Press, 2001).

${ }^{7}$ For attempts at similar descriptions in the ECHR context, see M. Delmas-Marty, Towards a Truly Common Law: Europe as a laboratory for legal pluralism (French ed. 1994, Cambridge: Cambridge University Press, trans. N. Norberg, 2002); E. Lambert, Les effets des arrêts de la Cour européenne des droits de l'homme: Contribution à une approche pluraliste du droit européen des droits de l'homme (Brussels: Emile Bruylant, 1999).

8 See N.W. Barber, 'Legal Pluralism and the European Union', European Law Journal 12 (2006) 306; on concepts of legal pluralism generally, J. Griffiths, 'What is Legal Pluralism?' (1986) 24 Journal of Legal Pluralism and Unofficial Law 1.

9 My use of 'constitutionalism' here corresponds to the thick sense of constitution in J. Raz, 'On the Authority and Interpretation of Constitutions: Some Preliminaries', in L. Alexander (ed.), Constitutionalism: Pbilosophical Foundations (Cambridge: Cambridge University Press, 1998) 152-193, at 153-154, and to the second and third sense of constitutionalism identified in P. Craig, 'Constitutions, Constitutionalism and the European Union' (2001) 7 European Law Journal 125, 127-128.

${ }^{10}$ See N. Krisch, 'Die Vielheit der Verfassung', in Y. Becker et al. (eds.), Die Europäische Verfassung Verfassungen in Europa (Baden-Baden: Nomos Verlag, 2005) 61-89, at 63-69.
} 
it helps crystallise the common aspirations and ground rules of a society. ${ }^{11}$ Unsurprisingly then, many have found it desirable to transfer this model from the nation state to European and global levels, as an analytical tool or as a normative aspiration. ${ }^{12}$ Yet in the postnational context, such a transfer might be inappropriate: contestation over fundamentals may simply be too strong to make a common set of ultimate norms an achievable or even desirable goal. Instead, in response to this contestation, we can observe the development of pluralist orders in a number of areas of postnational governance, ranging from the European Union to the global regulation of food safety. ${ }^{13} \mathrm{I}$ am generally interested in whether such pluralism can form an attractive countermodel to the constitutionalist one: how it operates, whether it is stable, and what benefits it has. ${ }^{14}$ The present paper seeks to generate insights into these questions through the study of a prominent example of supra- or international governance, the European human rights regime.

The paper proceeds in three main steps. In Part I, I will try to substantiate the claim that the friction apparent in Görgïlü is the norm rather than the exception in European human rights law. I attempt to do this through case studies of Spain and France, which are generally regarded as fitting the constitutionalist narrative of European human rights law well; in both, however, surface appearance and actual practice diverge considerably. In Part II, I will then try to show how the system, despite its pluralism and contestation about fundamentals, has come to work how mutual accommodation rather than friction has come to characterise its everyday operation. Here, I have chosen two orders - the European Union and the United Kingdom - which exhibit a strong pluralism on a formal level but a remarkable degree of harmony and convergence in practice, and I am interested in how this harmony has come about and why. In Part III, I will then draw on this material to reflect more generally on the respective values of pluralism and constitutionalism in the construction of a postnational legal order, and on some of the conditions for the stability and success of a pluralist structure.

\footnotetext{
${ }^{11}$ See, e.g., F. Michelman, 'Law's Republic' (1988) 97 Yale Law Journal 1493; B. Ackerman, We the People: Foundations (Cambridge, Mass.: Harvard University Press, 1991) 266-294; J. Habermas, Faktizität und Geltung (Frankfurt am Main: Suhrkamp Verlag, 1992) 109-165.

${ }^{12}$ On constitutionalist discourse on the European level, see, e.g., J.H.H. Weiler, 'The Reformation of European Constitutionalism', in J.H.H. Weiler, The Constitution of Europe (Cambridge: Cambridge University Press, 1999) 221-234; for similar proposals on the international level, see, e.g., J. Habermas, 'Hat die Konstitutionalisierung des Völkerrechts noch eine Chance?', in J. Habermas, Der gespaltene Westen (Frankfurt am Main: Suhrkamp Verlag, 2004) 113-193; and the symposium in the (2006) 19(3) Leiden Journal of International Law.

13 See, e.g., N. Walker, 'The Idea of Constitutional Pluralism' (2002) 65 MLR 317; N. Krisch, 'The Pluralism of Global Administrative Law' (2006) 17 European Journal of International Law 247.

14 I have conducted some preliminary work on this in other contexts; see N. Krisch, 'Europe's Constitutional Monstrosity' (2005) 25 OJLS 321; and Krisch, n 10 and 13 above.
} 


\section{THE OPENNESS OF EUROPEAN HUMAN RIGHTS LAW}

Even though the German judgment in Görgülü caused such concern, Germany had never been a model case for the constitutionalist story. The ECHR is incorporated into German law, but only with the rank of a statute. Its position is strengthened by a presumption that other statutes are not intended to violate it, and by the Constitutional Court's view, expressed since the 1980s, that it can have recourse to the Convention when interpreting fundamental rights in the Grundgesetr: Yet in practice, though actual friction has been rare, the ECHR has played a limited role in German jurisprudence, due in large part to the strength of domestic rights and the Constitutional Court's case-law on them. ${ }^{15}$

The constitutionalist story thus finds stronger support in other parts of Europe, with countries such as the Netherlands or Austria at the forefront, more recently reinforced by the high status the Convention enjoys in many of the new member states in Central and Eastern Europe. ${ }^{16}$ For the latter, the impact of the ECHR might still be too recent to allow relevant conclusions on the actual practice ${ }^{17}$, but also a case like Austria should give cause for reflection. It is certainly true that in Austria the Convention enjoys constitutional rank and that Austrian courts, especially the Austrian Constitutional Court, cite Convention articles as well as Strasbourg jurisprudence regularly and extensively.18 However, already in its 1987 Miltner judgment (which is remarkably similar to Görgülï), the Constitutional Court made it clear that there were limits to its loyalty to Strasbourg, and if the ECtHR stretched its law-making functions too far, it would not be able to follow it. ${ }^{19}$ The particular problem that provoked this holding was solved by legislation and open friction has been rare since, but the Miltner judgment has not been overturned and instances of Viennese resistance to Strasbourg remain..$^{20}$

In what follows, as indicated above, I will concentrate on two other cases that are generally seen to reflect the constitutionalist trajectory. This is particularly so for Spain where the ECHR enjoys supra-legislative status and is also a constitutionally mandated tool for the interpretation of the Spanish constitution;

\footnotetext{
15 See A. Zimmermann, 'Germany', in n 6 above, 335-354; J.A. Frowein, 'Der europäische Grundrechtsschutz und die deutsche Rechtsprechung' (2002) 21 Neue Zeitschrift für Verwaltungsrecht 29; C. Gusy, 'Die Rezeption der EMRK in Deutschland', in C. Grewe \& C. Gusy (eds.), Menschenrechte in der Bewährung: Die Rezeption der Europäischen Menschenrechtskonvention in Frankereich und Deutschland im Vergleich (Baden-Baden: Nomos, 2005) 129-158.

${ }^{16}$ See K. Chryssogonos, 'Zur Inkorporation der Europäischen Menschenrechtskonvention in den nationalen Rechtsordnungen der Mitgliedstaaten' (2001) 36 Europarecht 49.

${ }^{17}$ But see H. Keller, 'Reception of the European Convention for the Protection of Human Rights and Fundamental Freedoms (ECHR) in Poland and Switzerland' (2005) 65 Zeitschrift für ausländisches öffentliches Recht und Völkerrecht 283

${ }^{18}$ See H. Tretter, 'Austria', in n 6 above, 103-165.

19 Austrian Constitutional Court, Judgment of 14 October 1987, Miltner, VfSlg 11500/1987, available via http://www.ris.bka.gv.at/vfgh/.

20 On a recent problematic case, see W. Karl \& E.C. Schöpfer, 'Österreichische Rechtsprechung zur Europäischen Menschenrechtskonvention im Jahr 2004' (2006) 61 Zeitschrift für öffentliches Recht 151, 158$159,198-200$.
} 
as a result, the Spanish Constitutional Court is one of the most active in the reception of Strasbourg jurisprudence. In France, the reception process has been slower and less enthusiastic, but here, too, the constitution grants the Convention a rank above statutes, and French courts are generally regarded as having reflected this status with increasing faithfulness to Strasbourg. Yet in both cases, the stories are not as clear-cut as the narrative of gradual progress suggests.

\section{THE SPANISH EMBRACE AND ITS LIMITS}

At first sight, the situation in Spain seems straightforward. Spain is generally regarded as a particularly faithful follower of Strasbourg, and the Spanish constitutional court usually ranks among the national courts that cite the ECHR and Strasbourg jurisprudence the most. ${ }^{21}$ This is not surprising, given the importance of the Convention in the transition from Franco's dictatorship: as much as it was important for Spain on the international level to demonstrate membership in the club of Western democratic countries, its authority was of great use in stabilizing its new democratic institutions - and particularly the new Tribunal Constitucional - internally. ${ }^{22}$

As a result, the ECHR occupies an important position in the Spanish legal order. It ranks, like other treaties, above ordinary legislation ${ }^{23}$, but it is also central to the interpretation and development of the individual rights enshrined in the constitution. According to Article 10(2) of the constitution, the "basic rights and liberties ... shall be interpreted in conformity with the Universal Declaration of Human Rights and the international treaties and agreements on those matters ratified by Spain", and this has in practice meant primarily the ECHR. ${ }^{24}$ In recent years, the Tribunal Constitucional (TC) has cited the Convention in one out of five decisions, and in three out of four of its most important - plenary - decisions in

21 See only M.-A. Eissen, 'L'interaction des jurisprudences constitutionnelles nationales et de la jurisprudence de la Cour européenne des Droits de l'homme', in D. Rousseau \& F. Sudre (eds.), Conseil constitutionnel et Cour européenne des droits de l'homme: Droits et libertés en Europe (Paris: Editions STH, 1990) 137-215, 146-147.

22 On the constitutional history, see L. Martín-Retortillo Baquer, 'La recepción por el Tribunal Constitucional de la jurisprudencia del Tribunal Europeo de Derechos Humanos' (1995) 137 Revista de Administración Publica 7, 8, 12. On the concrete points of dispute over the insertion of a reference to international human rights instruments, see L. Martín-Retortillo Baquer, Notas para la historia del apartado segundo del artículo 10 de la Constitución', in L. Martín-Retortillo Baquer, La Europa de los derechos humanos (Madrid: Centro de estudios políticos y constitucionales, 1998) 177-192; A. Saiz Arnaiz, La apertura constitucional al derecho internacional y europeo de los derechos humanos. El artículo 10.2 de la Constitucion Española (Madrid: Consejo General del Poder Judicial, 1999) ch. 1.

23 Article 96(1) of the Spanish Constitution. The superior rank has been widely accepted, though only after some disputes in the literature; see G. Escobar Roca, 'Spain', in n 6 above, 809-831, at 812-813.

${ }^{24}$ On the special role of the ECHR, see STC 245/1991, FJ 3; STC 91/2000, FJ 7 (judgments of the Tribunal Constitucional are available via www.tribunalconstitucional.es/jurisprudencia/jurisprudencia.html). A. Queralt Jiménez, Los efectos interpretativos de las sentencias del Tribunal Europeo de Derechos Humanos. Especial consideración a la jurisprudencia del Tribunal Constitucional, Dissertation, Universitat de Barcelona, 2005, 583618, demonstrates the TC's preference for the ECHR over the International Covenant on Civil and Political Rights. 
individual rights cases ${ }^{25}$, and in a significant number of cases, it has referred to the Convention as the basis for substantial shifts in its case-law. ${ }^{26}$

Yet if Article 10(2) seems to demand the strict observance of the ECHR (and of ECtHR jurisprudence ${ }^{27}$ ) in the interpretation of individual rights, the clause "in conformity" ("de conformidad") has often been understood in a flexible way. ${ }^{28}$ Sometimes the TC suggests a tight link between the Convention and the content of constitutional rights, understanding Article 10(2) as "imposing" a certain reading ${ }^{29}$; but often enough, it uses more ambiguous formulae, describing the ECHR as an "interpretative criterion" that has to be "taken into account" in or should "orient" constitutional interpretation. 30 The actual status of the Convention in the interpretation of fundamental rights thus remains unclear; the TC keeps shifting ground, but ultimately retains flexibility as to the weight it accords Strasbourg judgments, and the ECHR in general.

The affirmation of this flexibility has been most noticeable in two very distinct clusters of cases. The first of them concerns the execution of judgments of the ECtHR in Spain. In Spain, as has long been the case in most of Europe, reopening proceedings after they have been closed by a final judgment faces high hurdles, and the ECtHR finding a Convention violation in a given case generally does not suffice. As a result, Spanish courts have traditionally not reacted to such findings, but in 1991, the TC initiated a shift and set aside a domestic judgment found to have violated the right to a fair trial. In the Bultó case, it held that because of Article 10(2) a violation of the ECHR constituted in itself also a violation of a constitutional right, and that as a consequence, the $\mathrm{TC}$ was under a duty to remedy this violation if no other means were available. ${ }^{31}$ This reasoning was radical enough a departure from traditional doctrine to provoke not only a very strong dissenting opinion but also an outcry in the scholarly literature; for the critics, the

\footnotetext{
${ }^{25}$ Queralt Jiménez, n 24 above, 311-315.

26 ibid, ch. 4 to 6. See also the cases in Saiz Arnaiz, n 22 above, 245-266; Escobar Roca, n 23 above, 815821. For an important instance of a shift, see, e.g., STC 167/2002 of 18 September 2002.

27 The TC does not make a difference between Convention and jurisprudence, recognizing that it is for the ECtHR 'to concretize the content of the rights recognized in the Convention'; STC 91/2000 of 30 March 2000, FJ 7. Likewise, most of the literature accepts that the status of ECtHR case-law is on a par with the Convention as such; see only E. García de Enterría, 'Valeur de la jurisprudence de la Cour européenne des Droits de l'Homme en droit espagnol', in F. Matscher \& H. Petzold (eds.), Protecting Human Rights: The European Dimension: Studies in honour of Gérard J. Wiarda (Cologne: Carl Heymann, 1988, 221-230, at 224; J. Delgado Barrio, 'Proyección de las decisiones del Tribunal Europeo de Derechos Humanos en la jurisprudencia española' (1989) 119 Revista de Administración Publica 233, 242-245. But see also Saiz Arnaiz, n 22 above, 167-168, who observes a lack of theoretical grounding in the TC's references to ECtHR decisions.

${ }^{28}$ See also Saiz Arnaiz, n 22 above, 207-208, 234-235.

${ }^{29}$ STC $147 / 2000$ of 29 May 2000, FJ 4a. For similar formulae, see STC 167/2002 of 18 September 2002, FJ 9; STC 206/1998 of 26 October 1998, FJ 4; STC 36/1991 of 14 February 1991, FJ 5.

${ }_{30}$ STC 119/2001 of 24 May 2001, FJ 6. Similar formulae can be found in STC 113/1987 of 3 July 1987, FJ 2; STC 24/1981 of 14 July 1981, FJ 4; STC 36/1984 of 14 March 1984, FJ 3. On other international instruments, see STC 38/1981 of 23 November 1981, FJ 4; STC 292/2000 of 30 November 2000, FJ 3; STC 70/2002 of 3 April 2002, FJ 7a.

31 STC 245/1991 of 16 December 1991; the ECtHR judgment was Barberà, Messegué and Jabardo v Spain of 6 December 1988. For a similarly strong linkage between constitutional right and ECHR, see STC 36/1991 of 14 February 1991, FJ 5.
} 
TC had tied the rights under the Spanish constitution too closely to the jurisprudence of the ECtHR. ${ }^{32}$ And indeed, the Tribunal Constitucional did not maintain this approach for long. Two years after Bultó, it departed from it rather silently in an unpublished decision in which it emphasised that the TC and the ECtHR operated "in distinct legal orders"; that the TC, subject only to the Spanish Constitution, enjoyed "independence in its task of interpretation under Article 10(2)"; and that it was in no way hierarchically subordinate to the Strasbourg court. ${ }^{33}$ This new position was a response to a Strasbourg decision in a case (Ruiz Mateos) that for more than ten years had attracted much public attention in Spain; and it might have been provoked by the fact that the ECtHR judgment presented a direct challenge to earlier decisions of the TC itself. ${ }^{34}$ However, the Tribunal has affirmed this more restrictive stance in a number of cases since ${ }^{35}$, and while the result might not differ much from the situation in other countries, the sequence of cases is remarkable as an attempt to reclaim supremacy (and flexibility) after experimenting with a closer link between national and European systems of human rights protection.

A similar dynamic emerges in the second set of cases, which also reflects a broader cultural gap between Spanish and European conceptions of rights. ${ }^{36}$ It concerns the effects of environmental pollution on the health and well-being of individuals; an issue that the ECtHR began to tackle from the angle of the right to a private life in the early 1990s. ${ }^{37}$ In 1994, it applied its approach in a Spanish case, Lopez Ostra, and found that the government had failed to protect the applicant sufficiently from the smells, noise and polluting fumes emanating from a waste treatment plant nearby. 38 The judgment met with much criticism in Spanish doctrine ${ }^{39}$, and initially with an evasive reaction by the TC. ${ }^{40}$ It was only seven years later that the Tribunal considered the possibility - suggested by the Strasbourg jurisprudence - of an extensive interpretation of the right to privacy

\footnotetext{
32 See only C. Ruiz Miguel, La ejecución de las sentencias del Tribunal Europeo de Derechos Humanos (Madrid: Tecnos, 1997) 138-151; also J.A. Carrillo Salcedo, 'España y la protección de los derechos humanos: el papel del Tribunal Europeo de Derechos Humanos y del Tribunal constitucional español' (1994) 32 Archiv des Völkerrechts 187, 199. But see also the more positive assessment in J.L. Requejo Pagés, 'La articulación de las jurisdicciones internacional, constitucional y ordinaria en la defensa de los derechos fundamentales' (1992) 35 Revista Española de Derecho Constitucional 179.

33 TC, Admissibility decision of 31 January 1994, Amparo no. 2292/93, in Ruiz Miguel, n 32 above, 181 183. The TC's attempts at distinguishing the case from the earlier one were rather weak; see ibid, 151-156. 34 ECtHR, Judgment of 23 June 1993, Ruiz-Mateos v Spain.

35 See ATC 96/2001 of 24 April 2001 (citing the admissibility decision of 11 March 1999) in the Castillo Algar case; STC 313/2005 of 12 December 2005, FJ 3, in the Perote Pellón case; and STC 197/2006 of 3 July 2006, in the Fuentes Bobo case; see also M. Revenga Sánchez, 'En torno a la eficacia de las Sentencias del TEDH: ¿Amparo de ejecución o afianzamiento de doctrina? Una propuesta de reforma' 2004 Revista española de Derecho Europeo 521, 527-529. But see also, for a slight shift regarding criminal cases, STC $240 / 2005$ of 10 October 2005, FJ 6.

36 On these cases, see also Queralt Jiménez, n 24 above, 511-531.

37 See especially ECtHR, 21 February 1990, Powell and Rayner v United Kingdom.

38 ECtHR, Judgment of 9 December 1994, López Ostra v Spain.

${ }^{39}$ Cf. Escobar Roca, n 23 above, 825.

40 STC 199/1996 of 3 December 1996, FJ 2-3, 6. Because the applicant sought the criminal prosecution of those responsible for pollution, the TC could also distinguish the case from that decided by the ECtHR in López. Ostra; see FJ 4.
} 
(intimidad) and to a home in the Spanish constitution. In the 2001 Moreno Gómez. case, the TC indeed affirmed that this right, as well as the right to physical integrity, might be affected by environmental factors, and in the particular case by an elevated level of outside noise. ${ }^{41}$ Yet it stopped short of subscribing fully to the ECtHR's approach, noting - in contrast to its previous jurisprudence - that Article 10(2) did not require a "literal translation" (traslación mimética) of ECtHR decisions, and pointing to the "normative differences" between the Convention and the constitution. ${ }^{42}$ Consequently, it set a high threshold for finding an interference with fundamental rights ${ }^{43}$, and in the present instance did not find that this threshold had been reached. This result, and the more restrictive approach in general ${ }^{44}$, are not surprising in a rather noisy country where tolerance levels are high; the difference in approach from much of the rest of Europe became evident when, three years later, the ECtHR unanimously found a violation of the right to a private life in the same case. ${ }^{45}$ What is interesting, however, is the fact that this difference has found reflection in the principles guiding the TC's reception of Strasbourg jurisprudence and has led to a result that is quite far removed from the "conformity" with the ECHR that Article 10(2) requires and that, thus far, had not been interpreted so liberally. ${ }^{46}$

The link between the Spanish constitution and the ECHR, very close in Bultó, later somewhat loosened but still tight, has thus become weaker, offering significant discretion to the Tribunal Constitucional in deciding when to follow Strasbourg and how. This should not make us overlook the fact that, as mentioned above, the TC refers to the ECHR and to ECtHR decisions very frequently and, in fact, as a matter of normalcy. But this practice appears less as a result of a principled linkage than as a favourable exercise of discretion by the TC in the great number of cases in which the stakes are not too high. ${ }^{47}$ For a Tribunal that is now in a much less precarious position than in the early years, preserving autonomy seems to have taken precedence over fostering close ties with Strasbourg.

\section{THE FRENCH DIALOGUE DES JUGES}

The French trajectory is quite different, though perhaps more typical of the general constitutionalist story. Initially convinced that the Convention was a way not to learn but to teach others, France long remained sceptical, ratified it only in

\footnotetext{
41 STC $119 / 2001$ of 24 May 2005, FJ 5.

42 ibid, FJ 6.

43 On the difference from the ECtHR's approach, see the analysis in Queralt Jiménez, n 24 above, 522 526.

${ }^{44}$ Later confirmed in STC 16/2004 of 23 February 2004.

45 ECtHR, Judgment of 16 November 2004, Moreno Gómez v Spain.

${ }^{46}$ For a similar approach with regard to the UN Human Rights Committee, see STC 70/2002 of 3 April 2002, FJ 7; Queralt Jiménez, n 24 above, 583-618.

${ }^{47}$ For a similar account, see Saiz Arnaiz, n 22 above, 160-161; for a normative defense of such a practice, see V. Ferreres Comella, 'El juez nacional ante los derechos fundamentales europeos. Algunas reflexiones en torno a la idea de diálogo', in Integración europea y poder judicial (Bilbao: Instituto Vasco de Administración Publica) 2006, 227-265, at 228-237, 244-249.
} 
1974 and waited until 1981 to accept individual complaints. Over time, however, the French political and judicial systems have grown increasingly open, reaching a stage where smooth reception is the rule and the constitutionally mandated superiority of the ECHR over domestic legislation is now widely accepted. ${ }^{48}$

In this picture, France is a story of gradual, if slow, progress. The Conseil constitutionnel, the equivalent to a constitutional court, rejects the use of the Convention as a standard against which it can measure statutes, but has over time become more receptive to the ECHR, adapting its jurisprudence on domestic liberties to Strasbourg case-law without mentioning it. ${ }^{49}$ The Cour de cassation began to recognize the ECHR's direct effect in the the mid-1970s, made use of it with growing readiness from the 1980s on, and it also reacted to Strasbourg judgments often with great speed.50 Today, commentators observe a normalisation, even "banalisation", of the Cour de cassation's use of the ECHR as a check on domestic legislation. ${ }^{51}$ The Conseil d'Etat, the highest administrative court, has shown greater reluctance and began to recognise the superior rank of the ECHR only in 1990. Since then, however, Strasbourg jurisprudence is reflected much more broadly, up to the point where the Conseil d'Etat, in a remarkable shift, has begun to cite ECtHR case-law. 52

Yet if this general picture reflects a strong domestic anchoring of the Convention and its case-law, it also conceals significant friction. Despite the primacy of the ECHR provided for in the constitution, French scholars and judges prefer to see the relationship between the legal orders as one of coordination and that of French and European judges as a "dialogue". ${ }^{3}$ In this vein, they often regard the authority of ECtHR judgments as limited, especially in cases France has

\footnotetext{
${ }^{48}$ See generally E. Steiner, 'France', in C.A. Gearty (ed.), European Civil Liberties and the European Convention on Human Rights (The Hague: Kluwer Law International, 1997); C. Dupré, 'France', in n 6 above, 313-333; L. Heuschling, 'Comparative Law and the European Convention on Human Rights in French Human Rights Cases', in E. Örücü (ed.) Judicial Comparativism in Human Rights Cases (London: UKNCCL and BIICL, 2003) 23-47; M. Fromont, 'Le juge français et la Cour européenne des droits de l'homme', in J. Bröhmer et al. (eds.), Internationale Gemeinschaft und Menschenrecbte: Festschrift für Georg Ress (Cologne: Heymann, 2005) 965-977.

49 See, e.g., O. Dutheillet de Lamothe, 'European Law and the French Constitutional Council', in G. Canivet, M. Andenas \& D. Fairgrieve (eds.), Comparative Law Before the Courts (London: BIICL, 2004) $91-$ 98; B. Mathieu 'De quelques examples récents de l'influence des droits européens sur le juge constitutionnel français' Dalloz 2002, no. 18, 1439-1441.

${ }^{50}$ See R. de Gouttes, 'Le juge judiciaire français et la Convention européenne des droits de l'homme: avancées et reticences', in P. Tavernier (ed.), Quelle Europe pour les droits de l'homme? (Bruxelles: Emile Bruylant, 1996) 217-234; R. de Gouttes, 'La Convention Européenne des Droits de l'Homme et le juge français', (1999) 51 Revue Internationale de Droit Comparé 7; Steiner, n 48 above, 294-298.

${ }^{51} \mathrm{P}$. Wachsmann, quoted in F. Sudre, 'Vers la normalisation des relations entre le Conseil d'Etat et la Cour européenne des droits de l'homme' 2006 Revue française de droit administratif, $286,287$.

52 See R. Abraham, 'Le juge administratif français et la cour de Strasbourg', in Tavernier, n 50 above, 235247; Sudre, n 51 above, especially 287-288; Conseil d'Etat, Decision of 20 December 2005, No. 288253.

53 See Abraham, n 52 above, 245-247; Sudre, n 51 above; J. Andriantsimbazovina, L'autorité des décisions de justice constitutionnelles et européennes sur le juge administratif français (Paris: LGDJ, 1998) 441-515; Heuschling, n 48 above, 35; also de Gouttes, 'Le juge judiciaire...', n 50 above, 234; and the similar approaches in L. Potvin-Solis, L'effet des jurisprudences européennes sur la jurisprudence du Conseil d'Etat français (Paris: LGDJ, 1999); Lambert, $n 7$ above.
} 
not been a party to. ${ }^{54}$ And even though the image of dialogue suggests harmony, it conceals, as one French scholar puts it, "the discrete but real play of power between jurisdictions and the capacity of resistance as well as adaptation". ${ }^{55}$

This capacity of resistance has indeed become apparent in a number of cases. It has been verbalised most strongly in the Conseil d'Etat, and in particular by its Commissaires $d u$ Gouvernement (CdG), the official amici of the Conseil. Already in 1978, one of them insisted that the Conseil d'Etat had "an autonomous and sovereign power of interpretation entirely comparable to the power to interpret domestic rules"; conflicts with the ECtHR were thus not solved legally, as a matter of principle, but should be avoided for reasons of "convenience and political realism". ${ }^{56}$ And still in 1997, another CdG stated that "when you apply the provisions of the Convention, you attach a lot of importance to the latest interpretation given by the European Court, but you cannot consider yourself as being legally bound by this interpretation". ${ }^{57}$

The limits of the ECtHR's authority over French courts became clearer in the dispute over the Poitrimol case - an example of resistance or, in the words of an advocate-general at the Cour de cassation, "rebellion" of French courts against Strasbourg. ${ }^{58}$ In its 1993 Poitrimol decision, the ECtHR regarded a classical element of French criminal procedure - the loss of the right of appeal for an accused who fails to appear in person - as a violation of the right to a fair trial. ${ }^{59}$ Over the next six years, despite further condemnations of France in Strasbourg ${ }^{60}$, French courts refused to set aside their procedural rules. At first, they ignored the ECtHR's judgment; later, they openly defied it by insisting on their own interpretation of Article 6 ECHR; and only in 1999 did the Cour de cassation shift its approach to some extent, thereby anticipating a legislative amendment adopted in 2000. ${ }^{61}$ In 2001, it finally accepted the authority of the ECtHR on a parallel issue, with the reporting judge noting "the superior principle of the European Convention, which takes precedence over our contrary domestic rules". ${ }^{2}$

\footnotetext{
54 On the scholarly dispute over whether Strasbourg jurisprudence enjoys interpretative authority at all, or whether French courts remain free to interpret the Convention themselves, see Heuschling, n 48 above, 30-32.

55 B. Mathieu, 'De quelques examples récents de l'influence des droits européens sur le juge constitutionnel français', Dalloz 2002, no. 18, 1439-1441.

${ }^{56}$ Conclusions of D Labetoulle, cited in Heuschling, $\mathrm{n} 48$ above, 32.

57 Conclusions of G Bachelier, cited ibid.

${ }^{58}$ De Gouttes, 'Le juge judiciaire...', n 50 above, 232-233.

59 ECtHR, Judgment of 23 November 1993, Poitrimolv France.

${ }^{60}$ ECtHR, Judgments of 29 July 1998, Omar v France, Guérin v France; Judgment of 14 December 1999, Khalfaoui $\mathrm{v}$ France.

${ }^{61}$ Cour de Cassation, Judgment of 19 January 1994, no. 93-80163, Bulletin criminel 1994, no. 27 p. 50; Judgment of 7 February 1994, no. 93-81533; Judgment of 9 January 1995, no. 94-81696, Bulletin criminel 1995, no. 7, 18; Judgment of 30 June 1999, Rebboah, no. 98-80923, Bulletin criminel 1999, no. 167, 478; also Judgment of 24 November 1999, Zutter, no. 97-85694, Bulletin criminel 1999, no. 273, 858. On the legislation, see the Law no. 2000-516 of 15 June 2000, Journal Officiel, n 138 , 16 juin 2000, 9038. See also M. Fromont, 'Die Bedeutung der Europäischen Menschenrechtskonvention in der französischen Rechtsordnung' (2005) 58 Die Öffentliche Verwaltung 1, 7.

${ }^{62}$ Cour de Cassation, Judgement of 2 March 2001, Dentico, no. 00-81388, Bulletin d'Information de la Cour de Cassation no. 533, 15 April 2001, www.courdecassation.fr/_BICC/bicc.htm, also with the report of the reporting judge and the conclusions of the advocate-general.
} 
The theoretical underpinnings of these years of resistance become a little more concrete in statements of one of the advocates-general at the Cour, Regis de Gouttes. In his view, the decisions in the wake of Poitrimol draw a limit of Strasbourg's authority in the "fundamental principles of French law" or in constitutional norms such as the effectiveness of the judiciary. ${ }^{63}$ If this interpretation is correct (and advocates-general's views are usually accorded much weight in the French legal system ${ }^{64}$ ), the situation in France does not differ much from that in Austria or Germany: French courts then do not merely disagree with Strasbourg on the interpretation of the ECHR but they set autonomous limits and protect a constitutional core from European interference. ${ }^{65}$ However, framing it in such principled terms should not hide the political context of French resistance in the Poitrimol case. Poitrimol was decided by a 5-4 majority in the ECtHR, with strong dissenting opinions, and there was thus reason for hope that the court might later change course. This hope crumbled when, in 1998, the ECtHR confirmed Poitrimol in two Grand Chamber judgments with majorities of 18-3 and 20-1, respectively.66 The ensuing shift of the Cour de cassation (and French legislation) was then likely due not so much to a shift in principle but to the "political realism" emphasised already in the above-mentioned CdG statement of 1978.

The situation was somewhat different in the second, and even more prominent, example of French judicial "rebellion", concerning the role of the judicial amici in French courts and especially the advocates-general at the Cour de cassation and the CdG at the Conseil d'Etat. ${ }^{67}$ In its 1991 Borgers decision, to the surprise of many observers, the Strasbourg court abandoned its earlier approach and found the privileged position of the advocate-general in the Belgian court of cassation to violate the right to a fair trial. ${ }^{68}$ This presented a challenge not only for Belgium, but also for similar courts in other countries ${ }^{69}$ and especially in France. Thus, the French Cour de cassation soon undertook a vigorous defence of its advocates-general: it made some procedural amendments and in a much-noted judgment, emphasised their impartiality and maintained the conformity of the institution with the idea of a fair trial..$^{70}$ However, the ECtHR was not impressed

\footnotetext{
${ }^{63}$ De Gouttes, 'Le juge judiciaire...' and 'La Convention...', n 50 above.

64 On their traditionally central role in French judicial decision-making, see M. Lasser, 'The European Pasteurization of French Law' (2005) 90 Cornell Law Review 995, 1005-1008.

${ }^{65} \mathrm{I}$ am grateful to Wibren van der Burg for insisting that I clarify this point.

66 ECtHR, Judgments of 29 July 1998, Omar v France and Guérin v France. In Omar, the French judge Pettiti was the only one to dissent. On the importance of these judgments for the Cour de cassation's change of approach, see the conclusions of the advocate-general de Gouttes, in Dentico, n 62 above.

67 See also the detailed assessment in Lasser, n 64 above.

68 ECtHR, Judgment of 30 October 1991, Borgers v Belgium; explicitly departing from Judgment of 17 January 1970, Delcourt v Belgium.

${ }^{69}$ ECtHR, Judgments of 20 February 1996, Vermeulen v Belgium and Lobo Machado v Portugal.

70 See Lasser, n 64 above, 1020; Cour de cassation, Judgment of 18 December 1996, Fontaine, No. 9682746.
} 
and in its 1998 Reinhardt and Slimane-Kaïd decision ${ }^{71}$, it found against France (though in a softer tone than in previous judgments and with less radical demands ${ }^{72}$ ), thereby initiating a process that eventually brought about significant changes in the Cour de cassation's organisation and procedure. ${ }^{73}$

If this attempt at resistance was thus largely unsuccessful, that of the Conseil d'Etat fared significantly better. Given the latter's similar structure, it was only a matter of time for it to come under ECtHR scrutiny as well; thus, shortly after the Reinhardt and Slimane-Kaïd judgment, the Conseil d'Etat decided to anticipate future cases and advance an own, alternative interpretation of the requirements of a fair trial, with an emphasis on the judicial role of the CdG: her being part of the judicial body and thus not subject to the adversarial procedure requirements in Article 6(1) of the Convention. ${ }^{74}$ This stance soon found support from the European Court of Justice (ECJ). Seeking to protect the role of its own advocates-general, the ECJ stressed that they acted as "Member[s] of the Court of Justice itself" and took part in the judicial function in full independence from outside authorities. ${ }^{75}$

With this move, both courts sought to distinguish themselves from institutions the ECtHR had already found wanting, including the French Cour de cassation - rather disingenuously so, given the largely parallel position of the judicial amici in all of them..$^{76}$ Nevertheless, this strategic stance, coupled with the strength of the concerted resistance, proved relatively successful. In its 2001 Kress judgment, the ECtHR recognized the special, "sui generis" nature of the CdG and, though pointing out that his independence and impartiality were not sufficient to remove all doubts regarding his role in the proceedings, the court proved far more lenient than in its earlier cases. ${ }^{77}$ It found the participation of the $\mathrm{CdG}$ in the deliberations of the bench to be in violation of the right to a fair trial, but gave carte blanche to its role in the proceedings before the Conseil d'Etat. Most significantly, and contrary to its stance in Reinhardt and Slimane-Kaïd, it did not question the privileged access of the CdG to the reporting judge's draft judgment prior to the hearings. ${ }^{78}$ Thus, the central procedural role of the $\mathrm{CdG}$ remained

${ }^{71}$ ECtHR, Judgment of 31 March 1998, Reinhardt and Slimane-Kaïd v France; affirmed in ECtHR, Judgment of 8 February 2000, Voisine v France; 26 July 2002, Meftah and others; 27 November 2003, Slimane-Kaïd (No 2); 5 February 2004, Weil.

72 See especially the observations in the dissenting opinion of Judge De Meyer, Judgment of 31 March 1998, Reinhardt and Slimane-Kaïd v France.

73 See Lasser, n 64 above, 1049-1051, 1060-1062; and the speech by procureur général Burgelin of 11 January 2002, available via http://courdecassation.fr/_rapport/rapport.htm.

${ }^{74}$ Conseil d'Etat, Judgment of 29 July 1998, Esclatine, Recueil Dalloz 1999, Jurisprudence, 89. See also the Conclusions of CdG Chauvaux, ibid, 85-89.

${ }^{75}$ ECJ, Order of 4 February 2000, Emesa Sugar, C-17/98, at [11-16].

${ }^{76} \mathrm{On}$ the independence and judicial function of the advocates-general at the Cour de cassation, see $\mathrm{J}$. Thierry, Case note, Recueil Dalloz 2000, Commentaires, 653-654; and the description in ECtHR, Judgment of 31 March 1998, Reinhardt and Slimane-Kaïd v France, at [74-75].

77 ECtHR, Judgment of 7 June 2001, Kress v France.

78 On this practice, see the description ibid, at [43]; the issue was not taken up in the assessment of the violation of the Convention; see also R. de Gouttes 'L'intervention du Ministère public au cours de la phase d'instruction: La situation à la Cour de cassation', in I. Pingel \& F. Sudre (eds.), Le ministère public et les exigences du procès équitable (Brussels: Bruylant, 2003) 63-80, at 72-74; B. Genevois, 'L'intervention du Ministère public au cours de la phase d'instruction: La situation au Conseil d'Etat', ibid, 81-93, 91. On a 
largely intact, and even though the Kress judgment has come under serious fire in the French literature ${ }^{79}$, it has also been described, more accurately, as "Solomonic". ${ }^{80}$ This has not, however, led the Conseil d'Etat to implement it in any meaningful way. In another round of resistance, encouraged by scholarly calls for only "modest, symbolic reforms" 81 , it has interpreted the judgment very narrowly, reading the condemnation of the CdG's "participation" in the deliberations of the bench as implying the possibility for him to "attend" these deliberations silently. ${ }^{82}$ This strategy, like that of the Cour de cassation in the Poitrimol episode, sought to exploit a division in the ECtHR: Kress was decided by a narrow majority of 10-7 in the Grand Chamber, with a vigorous joint dissent, thus indicating that there might be hope for a future shift. ${ }^{33}$ Yet Strasbourg did not flinch: in its 2006 Martinie decision, the Grand Chamber flatly - and with a clear 14-3 majority - rejected the challenge and upheld Kress, insisting that it could only be interpreted as ruling out not only active participation but also mere attendance of the CdG. ${ }^{84}$

The two episodes I have sketched here, around Poitrimol and Borgers, now allow us a slightly clearer picture of what the French vision of a "dialogue des juges" might imply. As we have seen, French practice now routinely follows ECtHR jurisprudence, but it ultimately reflects a "oui, mais..." vis-à-vis Strasbourg85, given the rejection of its interpretation in a few cases with high stakes. The conditions for this rejection are not clearly defined; we can discern a limit to Strasbourg's interpretative authority only in a notion as vague as "fundamental principles of French law". ${ }^{86}$ Yet this vagueness may, again, be useful: it allows the courts great flexibility; they can stage resistance against the ECtHR whenever they think its interference in French law and institutions has gone too far; and they can also take into account the political context, most notably the chances of changing Strasbourg jurisprudence, as we have seen in the Cour de cassation's attack on Poitrimol and the Conseil d'Etat's challenge of Kress. Thus,

point left vague in Kress, the precise form in which the parties are informed about the tenor of the CdG's conclusions and can respond to them, the ECtHR and the Conseil d'Etat engaged in another exchange; see Sudre, n 51 above, 292.

79 See only J. Andriantsimbazovina, 'Savoir n'est rien, imaginer est tout': libre conversation autour de l'arrêt Kress de la Cour européenne des droit de l'homme' Recueil Dalloz 2001, 2611-2618; V. Haïm, 'Fautil supprimer la Cour européenne des droits de l'homme' Recueil Dalloz 2001, 2988-2994.

80 R. Drago, Case note, Recueil Dalloz 2001, 2624-2627, at 2626; see also Andriantsimbanzovina, n 79 above, 2617.

${ }^{81}$ Drago, n 80 above, 2626.

82 See B. Genevois, 'L'intervention du Ministère public au cours du délibéré: La situation au Conseil d'Etat', in Pingel \& Sudre, n 78 above, 189-197, 196-197; Sudre, n 51 above, 291-297. The French response took the form of two directions of the president of the judicial division of the Conseil d'Etat of 2001 and 2002 and a governmental decree of 2005; see ECtHR, Judgment of 12 April 2006, Martinie v France, at [52], and the Decree no. 2005-1586 of 19 December 2005, in Revue française de droit administratif 2006, 298-299.

83 On this hope see, e.g., Sudre, n 51 above, 293.

${ }^{84}$ ECtHR, Judgment of 12 April 2006, Martinie v France. See also, in the same vein, the chamber judgment of 5 July 2005 in Marie-Louise Loyen and other $\mathrm{v}$ France, at [63].

${ }^{85}$ De Gouttes, 'Le juge judiciaire...', n 50 above, 219.

86 Criteria are similarly vague in the approaches of Andriantsimbanzovina, L'autorité..., n 53 above; Potvin-Solis, n 53 above. 
if the idea of "dialogue" favours transnational judicial conversations about principled questions of interpretation, it also opens space for discretion and realism: in short, for judicial politics. ${ }^{87}$ The joint between the French legal order and the ECHR is thus buffered by a political element - an element that is not fully determined by law but leaves the relationship, to an important extent, open.

\section{MUTUAL ACCOMMODATION IN A PLURALIST ORDER}

As the Spanish and French cases show, even in countries generally regarded as examples of the constitutionalist story, progress in the direction of a unified, wellordered European human rights law with the ECHR at its top is not unequivocal. The challenges to the constitutionalist narrative are not only factual, in that domestic courts sometimes do not follow Strasbourg judgments, evade them or misinterpret them. They are instead of a principled nature: domestic courts assert a power to decide on the limits of the authority of the ECtHR, and because of the very vague indications as to when this power can be exercised, it appears as essentially discretionary. In this, the French and Spanish cases are very similar to the German and Austrian ones mentioned at the beginning. The Austrian Constitutional Court saw the limits to Strasbourg authority in the "constitutional principles of state organisation" 88 , and according to the German Constitutional Court, ECtHR judgments have to be "taken into account" by German courts but may have to be "integrated", i.e. adapted to fit into the domestic legal system; they have to be fully disregarded when they run counter to legislative intention or are "contrary to German constitutional provisions". ${ }^{89}$ The German threshold for disregarding Strasbourg decisions thus appears lower than in the other cases considered, but the standards are similarly vague and allow the Constitutional Court to decide with wide discretion when it wants a decision to be followed and when not. ${ }^{90}$

In all those cases, from the perspective of the domestic courts national constitutional norms emerge as ultimately superior to European human rights norms and national courts as the final authorities in determining their relationship. This seems to hold more broadly: asked about their relationship to Strasbourg, 21 out of 32 responding European constitutional courts declared themselves not bound by ECtHR rulings. ${ }^{91}$ This contrasts with the constitutionalist narrative, but it much resembles the situation in European Union law, where - in the influential

\footnotetext{
${ }^{87}$ See also the observation in Potvin-Solis, ibid, 728.

88 See the Miltner judgment, n 19 above.

${ }^{89}$ See the Görgülï judgment, n 1 above, at [58], [62].

90 The German Constitutional Court has explicitly reserved its right to supervise the interpretation of these guidelines by lower courts, see ibid, at [63].

${ }^{91}$ M. Melchior \& C. Courtoy, 'The Relations between the Constitutional Courts and the Other National Courts, Including the Interference in this Area of the Action of European Courts: Part III' (2002) 23 Human Rights Law Journal 327, 327.
} 
interpretation of Neil MacCormick - two different systemic perspectives conflict and both the European and the national legal orders, through their respective courts, claim to wield ultimate authority. ${ }^{92}$ The relationship between the two levels is then determined not by one overarching rule, but by an oversupply of competing rules, among which solutions can only be found through political negotiations, often in the form of judicial politics.

If this sounds highly conflictual, reality has proven to be rather harmonious. We have already seen in the cases of Spain and France how, despite national courts' insistence on their final authority, the normal, day-to-day operation of the relationship with the Strasbourg Court has lately been highly cooperative, and friction has been rare. This picture seems, apart from a few exceptions, generalisable: compliance rates with ECtHR judgments are regarded as high (even though there are no systematic studies on the issue) $)^{93}$, and national courts in many jurisdictions refer to Strasbourg jurisprudence as a matter of normalcy.94 Also in Germany, despite the reservations of the Constitutional Court and a certain reluctance of courts to cite ECtHR cases, Strasbourg judgments are generally followed, sometimes without openly acknowledging that they are at the origin of a jurisprudential shift.95 Even - or especially - after Görgülï, the Bundesverfassungsgericht has come to analyse Strasbourg case-law in quite some detail 96 , and its president has emphasized the cooperative nature of the relationship between the courts. ${ }^{97}$

If we want to understand how this harmony in the face of a pluralist order has come about, we have to take a closer look at the judicial strategies and the interplay between the different courts. For this purpose, I have chosen to look at two cases in which the formal framework is obviously pluralist, thus clearly leaving domestic courts room for distancing themselves from Strasbourg if they so wish. The United Kingdom is one such case, as the 1998 Human Rights Act explicitly leaves the status of ECtHR judgments open; the other is the European Union, which is not even a party to the ECHR, with the result that any effect of Convention rights on the EU legal order and ECJ jurisprudence can always only be indirect. The aim of this inquiry is not to provide a comprehensive account of the gradual construction of the ECtHR's authority; this would be beyond the scope of this article. ${ }^{98} \mathrm{My}$ aim is more modest: to gain insights into why the

\footnotetext{
${ }^{2}$ N. MacCormick, 'Beyond the Sovereign State' (1993) 56 MLR 1; see also C. Richmond, 'Preserving the Identity Crisis: Autonomy, System and Sovereignty in European Law' (1997) 16 Law and Philosophy 377.

93 See Greer, n 4 above, 60-135.

$94 \mathrm{Cf}$. the surveys in $\mathrm{n} 6$ above.

95 See n 15 above.

96 See, e.g., Bundesverfassungsgericht, Judgment of 13 December 2006, 1 BvR 2084/05, available at http://www.bverfg.de/entscheidungen/rk20061213_1bvr208405.html (on membership in a hunting association).

97 H.-J. Papier, 'Koordination des Grundrechtsschutzes in Europa - die Sicht des Bundesverfassungsgerichts', Zeitschrift für Schweizerisches Recht 124 (2005) II, 113-127, at 127; 'Straßburg ist kein oberstes Rechtsmittelgericht', n 2 above.

98 We still lack general studies on the construction of the ECtHR's authority; for an initial attempt, see L.R. Helfer \& A.-M. Slaughter, 'Toward A Theory of Effective Supranational Adjudication' (1997) 107
} 
different courts have not used their discretionary space in a more conflictual way, and thereby to begin to understand how the pluralist structure has favoured or hampered the creation of a stable legal and political order in the context of the ECHR

\section{JUDICIAL CONVERSATIONS BETWEEN EUROPEAN COURTS}

Rather surprisingly, the relationship between the ECtHR and the European Court of Justice (ECJ) is not so dissimilar to the French and Spanish pictures, even though it rests on a fundamentally different basis. On a purely formal level, the ECHR and the law of the European Communities (EC) have long been unconnected: since the EC is not a party to the ECHR, Community acts remain outside the jurisdiction of the Strasbourg organs, and neither the Convention nor judgments of the Strasbourg Court create direct obligations for the EC. Yet despite this clear separation - a strong formal pluralism - the Strasbourg and Luxembourg courts have initiated a dialogue that, over time, has led to a remarkable convergence between their legal orders. ${ }^{99}$

Their relationship has evolved in broadly three phases, but though the trajectory might look like steady progress overall, it was not without frictions and setbacks. Initially, engagement between the judicial systems was very limited. In its early years, the ECJ refused to deal with human rights issues altogether; only faced with growing concerns among member states and their constitutional courts did it begin to regard fundamental rights as general principles of Community law, and from the mid-1970s on it mentioned the ECHR explicitly. ${ }^{100}$ Throughout this time, and until the late 1980s, the European Commission of Human Rights (EComHR) declared inadmissible all applications directed against Community acts solely on the ground that the EC was not a party to the Convention. ${ }^{101}$ This changed with the increase in the EC's human rights-sensitive functions, and in 1990, the EComHR held that member states had to ensure a level of protection "equivalent" to that of the ECHR when they transferred powers to the EC - a requirement it found to be met at that point. ${ }^{102}$

In the early 1990s, the relationship thus seemed to be one of harmony at a relatively safe distance; and it improved further with political efforts to make the

Yale Law Journal 273. Much more work has been done on the European Union; see only A.-M. Slaughter, A. Stone Sweet \& J.H.H. Weiler (eds.), The European Courts and National Courts (Oxford: Hart, 1997); K. Alter, Establishing the Supremacy of European Law: The Making of an International Rule of Law in Europe (Oxford: Oxford University Press, 2001); A. Stone Sweet, The Judicial Construction of Europe (Oxford: Oxford University Press, 2004).

${ }^{99}$ In this discussion, I am much indebted to L. Scheeck, 'The Relationship between the European Courts and Integration through Human Rights' (2005) 65 Zeitschrift für ausländisches öffentliches Recht und Völkerrecht 837.

100 On the general development, see B. de Witte, 'Community Law and National Constitutional Values', (1991) 18(2) Legal Issues of European Integration 1; A. Stone Sweet, 'Constitutional Dialogues in the European Community', in Slaughter, Stone Sweet \& Weiler, n 98 above, 305-330, at 317-319.

101 EComHR, Decision of 10 July 1978, Conféderation Française Démocratique du Travail v EC, alternatively: Their Member States, Decisions and Reports 13, 231.

102 EComHR, Decision of 9 February 1990, M $\approx$ Co v Germany, Decisions and Reports 64, 138. 
EC accede to the ECHR. These efforts were, however, brought to a halt in 1996 when the ECJ, in its famous Opinion 2/94, found the EC lacked the powers to accede: integrating it into the institutional framework of the Convention (i.e., subjecting its organs, including the ECJ, to the ECtHR) was of constitutional importance and thus required a formal amendment of the treaties. ${ }^{103}$ The ECtHR countered with what is widely regarded as a "warning shot" for Luxembourg. ${ }^{104}$ In its Cantoni judgment, it left the deferential path staked out earlier and subjected to full scrutiny a French provision identical to an EC directive, thus effectively denying Community acts the privileged treatment the "equivalent protection" doctrine implied. ${ }^{105}$ In the following years, the ECJ improved its record, citing ECtHR judgments more frequently and in greater detail ${ }^{106}$ and even using them in 1998 to hold, for the first time, that a Community act violated fundamental rights. ${ }^{107}$ The ECtHR, though, continued to assert itself: in its 1999 Matthews judgment, it applied normal Convention standards to the exclusion of Gibraltar from elections to the European Parliament, finding the United Kingdom in violation of the right to free and fair elections. ${ }^{108}$

Matthews was widely seen as signalling a willingness on the part of Strasbourg to extend its control into the area of EC law with greater self-confidence. ${ }^{109}$ Yet it was followed by a much calmer period. Over the next six years, the ECtHR found all challenges, direct or indirect, of EU measures to be inadmissible on grounds unrelated to the character and legal status of the EU, thus leaving the door open for scrutiny in principle but avoiding friction in the particular case. ${ }^{110}$ This deferential stance was sometimes surprising, for example in the Emesa Sugar case in which the ECJ had challenged Strasbourg's jurisprudence on the role of the Advocate General. ${ }^{111}$ In another high-profile case, Senator Lines, evasion became possible when the EU's Court of First Instance (CFI) quashed the respective fine shortly before the Strasbourg judgment was to be rendered, prompting suspicions that the CFI's decision might have been driven by strategic concerns. ${ }^{112}$ Overall, the ECJ's approach during this time certainly facilitated the ECtHR's cautious attitude: references to Strasbourg jurisprudence had become normal, several

\footnotetext{
103 Opinion 2/94 of 28 March 1996, ECR 1996, I-1759, at [34-36].

104 See D. Spielmann, 'Human Rights Case Law in the Strasbourg and Luxembourg Courts: Conflicts, Inconsistencies, and Complementarities', in P. Alston (ed.), The EU and Human Rights (Oxford, New York: Oxford University Press, 1999) 757-780, 773; also Scheeck, n 99 above, 865-866.

105 ECtHR, Judgment of 22 Oct 1996, Cantoni v France.

106 See, e.g., ECJ, Judgment of 26 June 1997, C-368/95, Familiapress, ECR 1997, I-3689, at [24-26].

107 ECJ, Judgment of 17 Dec 1998, C-185/95, Baustablgewebe, ECR 1998, I-8417.

108 ECtHR, Judgment of 18 Feb 1999, Matthews v United Kingdom, at [31-35].

109 See I. Canor, 'Primus inter pares. Who is the ultimate guardian of fundamental rights in Europe?' (2000) 25 European Law Review 3; Scheeck, n 99 above, 866.

110 See ECtHR, Decision of 23 May 2002, Segi and Gestoras Pro-Amnistia v Germany and others; Decision of 10 March 2004, Senator Lines v the 15 Member States of the European Union; Decision of 13 Jan 2005, Emesa Sugar BV v Netherlands; see also C. Costello, 'The Bosphorus Ruling of the European Court of Human Rights: Fundamental Rights and Blurred Boundaries in Europe’ (2006) 6 Human Rights Law Review 87, 94 96.

111 See ECJ, Emesa Sugar, n 75 above; on the French side of the same story, see text at n 67-84 above.

112 See CFI, Judgment of 30 Sept 2003, T-191/98 et al, Atlantic Container Line and others, ECR 2003, II3275; see Scheeck, n 99 above, 866-868.
} 
judgments reflected a greater emphasis on human rights as opposed to economic freedoms ${ }^{113}$, and in some much-noted instances the ECJ rectified inconsistencies between its jurisprudence and ECtHR judgments. ${ }^{114}$ This friendly interplay between the courts mirrored political developments - the ECHR was granted a prominent place in the EU Charter of Fundamental Rights in 2000115; and the draft constitutional treaty of 2004 contained an obligation for the EU to accede to the Convention. ${ }^{116}$ When ratification of the treaty failed, however, the ECtHR stepped back to the fore and used its Bosphorus judgment to set out with greater clarity its vision of the relationship with EU law.117 Accepting that "equivalent protection" was generally assured in the EU, it established that it would only scrutinize individual cases for "manifest deficiencies" in rights protection. In the case before it, it did not find such deficiencies, but the approach leaves it significant flexibility to react to changes in the EU's fundamental rights regime and also points to areas of EU law that might come under more intense scrutiny in the future. ${ }^{118}$

The product of these more than thirty years of interaction is significant convergence and harmony, and this is generally acknowledged by commentators, including the president of the ECtHR. ${ }^{119}$ The ECJ has come to refer to the ECHR and Strasbourg case-law as a matter of normalcy and usually follows it diligently; likewise, the ECtHR has acknowledged the generally satisfactory level of rights protection in the EU and has, with its "manifest deficiency" standard, raised the bar for individual challenges. ${ }^{120}$ Yet this mutual accommodation remains a matter of choice: the ECtHR retains flexibility in applying its standard; and the ECJ has never acknowledged being tied to Strasbourg's interpretation of the ECHR and has instead used vague notions such as "source of inspiration" to describe its status, leaving open the possibility of divergence when the ECJ regards it as necessary. ${ }^{121}$ To some extent, that stance has also been politically ratified: in the

113 ECJ, Judgment of 12 June 2003, C-112/00, Schmidberger, ECR 2003, I-5659; Judgment of 14 Oct 2004, C-36/02, Omega Spielhallen, ECR 2004, I-9609.

114 See especially ECJ, Judgment of 22 Oct 2002, C-94/00, Roquette Frères, ECR 2002, I-9011, explicitly departing from the decision in ECJ, Judgment of 21 Sept 1989, Case C-227/88, Hoechst, ECR 1989, 2859. ${ }^{115}$ Charter of Fundamental Rights of the European Union, O. J. 2000, C 364/1, Preamble and Arts 52(3) and 53; see below for more detail.

116 Treaty establishing a Constitution for Europe, O. J. 2004, C 310, Art. I-9 and Part II. The ECHR sought to allow for this in Additional Protocol No. 14.

117 ECtHR, Judgment of 30 June 2005, Bosphorus Hava Yollar Turizm v Ireland, especially at [152-158].

118 See Costello, $n 110$ above, 115-118.

${ }^{119}$ See O. de Schutter, 'L'influence de la Cour européenne des droits de l'homme sur la Cour de justice des Communautés européennes', CRIDHO Working Paper 2005/07, 3; Costello, n 110 above, 114; Wildhaber, quoted ibid.

${ }^{120}$ For other ways of interaction between the courts, see Scheeck, n 99 above, 868-877; S. Douglas-Scott, 'A Tale of Two Courts: Luxembourg, Strasbourg and the Growing European Human Rights Acquis' (2006) 43 Common Market Law Review 629, 640-644.

121 See, e.g., ECJ, Omega Spielhallen, n 113 above, at [33]. D. Simon, 'Des influences réciproques entre CJCE et CEDH: 'Je t'aime, moi non plus?" 2001 (96) Pouvoirs 31, 37, points out that the acceptance of the ECHR by the ECJ only operates 'within the framework of the structure and objectives of the EC'. On instances of problematic application of the Convention by the ECJ, see Spielmann, n 104 above, 766-770; De Schutter, n 119 above, 15-20, 25-26; Douglas-Scott, n 120 above, 656-657; C. Costello \& E. Browne, 
convention drafting the Charter of Fundamental Rights, some members wanted to see a reference to the ECtHR's case-law as a guide to interpretation, but this was successfully opposed by other members eager not to curtail the ECJ's autonomy by subjecting it directly to another body. ${ }^{122}$ In the end, the reference to Strasbourg jurisprudence was included only in the presidium's explanations. ${ }^{123}$

The overall result is far from hierarchical and well-ordered: it might not quite be of "Kafkian complexity" 124 , but it is certainly highly pluralist. How then has it come to be so harmonious in practice? The most obvious explanation would start from the particular situation the courts found (and still find) themselves in: for most of their existence, both have been highly vulnerable and their authority has been shaky. 125 In that context, the ECtHR may have wanted to subject the EC and later the EU to fuller control, given the gap in human rights protection that widened with the increase in supranational competences. But doing so too aggressively would have risked a backlash from the ECJ that could have been harmful to the ECtHR's position. Moving cautiously, recalibrating its approach according to the ECJ's reaction and the broader legitimacy context it was operating in, was thus the more sensible option. ${ }^{126}$ Likewise, for the ECJ, avoiding conflict with the ECtHR was of central importance. Its authority had been called into question in the 1960s and 1970s on human rights grounds, and using the ECHR was the most obvious way to allay concerns of national courts, governments and the public. Following the ECtHR was therefore only prudent: in order to maintain its authority, the ECJ had to accept constraints on its autonomy, even if it managed to keep these constraints limited, first by blocking the EC's accession to the ECHR and then by using vague formulae to describe the Convention's status in Community law.

\section{THE BRITISH TURN TOWARD STRASBOURG}

If the ECJ reached out to Strasbourg to bolster its authority, it seems the British House of Lords hardly needed such support: resting on centuries of tradition, it could easily forego the additional authority (if any) that a "European", or "foreign", court had to offer. So we might expect that the Lords, if given the

'ECHR and the European Union', in U. Kilkelly (ed.), ECHR and Irish Law (Bristol: Jordan Publishing, 2004), 35-80, at 41-46.

122 See J.B. Liisberg, 'Does the EU Charter of Fundamental Rights Threaten the Supremacy of Community Law?', Jean Monnet Working Paper 4/01, 7-18; also P. Lemmens, 'The Relation between the Charter of Fundamental Rights of the European Union and the European Convention on Human Rights - Substantive Aspects' (2001) 8 Maastricht Journal of European and Comparative Law 49, 50-55. In the end, the reference to Strasbourg jurisprudence was included only in the presidium's explanations; see Doc. Charte 4473/00 Convent 49, Explanation on Art. 52.

123 See Doc. Charte 4473/00 Convent 49, Explanation on Art. 52.

124 Douglas-Scott, n 120 above, 639.

125 See Scheeck, n 99 above, 870-873, 880-883; Costello, n 110 above, 88-89.

126 Bringing the ECJ on its side was also useful as a way of strengthening the enforcement of the ECHR within member states, at least as far as their action fell into the ambit of Community law and thus of ECJ supervision; on the latter, see J.H.H. Weiler \& N.S. Lockhart, 'Taking Rights Seriously' Seriously: The European Court and its Fundamental Rights Jurisprudence’ (1995) 32 Common Market Law Review 51, 579. 
choice, would insist on their autonomy and keep the ECtHR at a comfortable distance.

Yet this is not quite what happened. To be sure, before the 1998 Human Rights Act (HRA), the Convention was not part of British law and domestic courts only used the ECHR in a limited way, mostly to clarify ambiguities in statutes and the common law, but largely avoiding questions of judicial review of administrative action. ${ }^{127}$ However, the situation changed radically - surprisingly radically - with the HRA: in the few years since it has come into effect, British courts have come to refer to the Convention and to ECtHR judgments with a frequency and diligence hardly matched anywhere else in Europe. ${ }^{128}$ This is all the more surprising as the HRA only requires national courts to "take into account" Strasbourg jurisprudence in the interpretation of these rights. This vague formula deliberately creates opportunities for divergence; the government intended it to give domestic courts space to go beyond Strasbourg interpretations but also, for example, to disregard outdated judgments. ${ }^{129}$ But the House of Lords has refused to make use of this space: the dominant position among the judges is instead one of close attention and loyalty to Strasbourg judgments. This line is reflected in an opinion of Lord Bingham in 2004:

While such case law [of the ECtHR] is not strictly binding, it has been held that courts should, in the absence of some special circumstances, follow any clear and constant jurisprudence of the Strasbourg court ... This reflects the fact that the Convention is an international instrument, the correct interpretation of which can be authoritatively expounded only by the Strasbourg court. From this it follows that a national court subject to a duty such as that imposed by section 2 should not without strong reason dilute or weaken the effect of the Strasbourg case law. ... The duty of national courts is to keep pace with the Strasbourg jurisprudence as it evolves over time: no more, but certainly no less. ${ }^{130}$

\footnotetext{
127 See M. Hunt, Using Human Rights Law in English Courts (Oxford: Hart Publishing, 1997) chs. 4 to 6, for a detailed survey; also K. Starmer \& F. Klug, 'Incorporation through the Back Door' Public Law 1997, 223-233; R. Blackburn, 'The United Kingdom', in Blackburn \& Polakiewicz, n 6 above, 935-1008, at 950956, 971-991, 999-1003.

128 See only K. Starmer \& F. Klug, 'Incorporation through the 'Front Door': The First Year of the Human Rights Act' Public Law 2001, 654-665; C. O’Brien \& F. Klug, 'The First Two Years of the Human Rights Act' Public Law 2002, 649-662. See also the more cautious assessment in N. Bamforth, 'Understanding the Impact and Status of the Human Rights Act 1998 within English Law', NYU Global Law Working Paper 10/2004; E. Wicks, 'Taking Account of Strasbourg? The British Judiciary's Approach to Interpreting Convention Rights' (2005) 11 European Public Law 405, 410-425.

${ }^{129}$ Cf. Wicks, n 128 above, 406-409; R. Masterman, 'Taking the Strasbourg Jurisprudence into Account: Developing a 'Municipal Law of Human Rights' under the Human Rights Act' (2005) 54 The International and Comparative Law Quarterly 907, 912-913.

${ }^{130}$ House of Lords, Judgment of 17 June 2004, R v Special Adjudicator ex parte Ullah, [2004] UKHL 26, at [20]. For the initial statements, see Lord Slynn's speeches in House of Lords, Judgment of 9 May 2001, Alconbury, [2001] UKHL 23, at [26]; Judgment of 16 October 2003, R v Home Secretary ex parte Amin, [2003] UKHL 51, at [44].
} 
Formulae such as "special circumstances" or "without strong reason" still leave the courts significant flexibility and have also led to open departures from ECtHR interpretations. ${ }^{131}$ Yet the House of Lords follows Strasbourg case-law in most cases, and this includes politically highly sensitive judgments such as $A v$ Home Secretary where the Lords found statutory powers to detain terrorist suspects incompatible with the Convention. ${ }^{132}$ Even where they have an opinion that is difficult to reconcile with ECtHR judgments, they usually go to great lengths to achieve reconciliation through detailed exegesis and thus maintain the authority of the Strasbourg court. ${ }^{133}$ And when a Strasbourg verdict is in open conflict with their own previous jurisprudence, they see themselves as "required" to overturn the precedent. ${ }^{134}$

This strong loyalty to Strasbourg is unexpected also because of the generally nationalist sentiment prevailing in Britain - a sentiment likely to lead the Lords to read the open "take into account" language in the HRA as an invitation to start building an own, British human rights jurisprudence. ${ }^{135}$ This alternative was readily available: it could build on efforts to develop a rights-based "common law constitutionalism" already undertaken by courts and commentators since the late 1980s. ${ }^{136}$ And it is precisely this path that the Court of Appeal has taken in the wake of the HRA. In several judgments, it has declared that the 1998 Act charges the courts with "develop[ing] a municipal law of human rights by the incremental method of the common law, case by case, taking account of the Strasbourg jurisprudence"; that it did not need to "stick[ like glue to the Strasbourg texts"; or that its task was only to "draw out the broad principles which animate the Convention". ${ }^{137}$ In some cases, this has allowed the Court of Appeal to go beyond

131 See Lord Rodger, in House of Lords, Judgment of 18 July 2002, Boyd, Hastie and Spear Saunby and Others, [2002] UKHL 31, at [92] (the ECtHR judgment in question was seen to rely on incomplete information about the domestic situation). For the generally loyal attitude of Lord Rodger, see House of Lords, Judgment of 11 December 2003, Attorney General's Reference No 2 of 2001, [2003] UKHL 68, at [162].

132 See only House of Lords, Judgment of 16 December 2004, A v Home Secretary (Belmarsh), [2004] UKHL 56; Judgment of 10 April 2003, Bellinger v Bellinger, [2003] UKHL 21; Judgment of 8 March 2006, Lambeth and Leeds, [2006] UKHL 10.

133 See, e.g., Lord Hope in Lambeth and Leeds, n 132 above. But see also the more ambiguous stance in R (Hurst) v Commissioner of the Police, [2007] UKHL 13, and in cases involving privacy and freedom of expression, for example Campbell v MGN, [2004] UKHL 22; cf. G. Phillipson, 'Transforming Breach of Confidence? Towards a Common Law Right of Privacy under the Human Rights Act' (2003) 66 MLR 726; R. Mulheron, 'A Potential Framework for Privacy? A Reply to Hello? (2006) 69 MLR 679. I am grateful to Carol Harlow for drawing my attention to this latter point.

134 See, e.g., Lord Brown in Lambeth and Leeds, n 132 above, at [198].

${ }^{135}$ For a suggestion in this direction, see Masterman, n 129 above.

136 See M. Loughlin, 'Rights Discourse and Public Law Thought in the United Kingdom', in G.W. Anderson (ed.), Rights and Democracy: Essays in UK-Canadian Constitutionalism (London: Blackstone Press, 1999) 193-213; T. Poole, 'Back to the Future? Unearthing the Theory of Common Law Constitutionalism' (2003) 23 OJLS 435; also Hunt, n 127 above.

137 See Court of Appeal, Judgment of 6 March 2002, Tower Hamlets v Runa Begum, [2002] EWCA Civ 239, at [17]; Judgment of 27 March 2002, R (Amin) v Home Secretary, [2002] EWCA Civ 390, at [61-62]; Judgment of 17 May 2001, Aston Cantlow, [2001] EWCA Civ 713, at [43]. 
early Strasbourg jurisprudence and establish more demanding standards ${ }^{138}$, but in others it has been criticised for neglecting the ECtHR's case-law ${ }^{139}$ and falling short of what it required. ${ }^{140}$ In the House of Lords, a similar approach is taken by Lord Hoffmann who insists that Convention rights under the HRA have become domestic, not international rights, and that, when faced with ECtHR judgments that are based on a misunderstanding of British law or are "fundamentally at odds with the distribution of powers under the British constitution", courts might not have to follow them. ${ }^{141}$

If such a reserved stance would have been expected, it is all the more surprising that Lord Hoffmann is quite alone with it in the House of Lords. ${ }^{142}$ How can we explain the strong loyalty of the Lords to Strasbourg? The most straightforward answer would see dynamics of judicial empowerment at work: by relying on Strasbourg authority, the House of Lords was able to extend the reach of its judicial review powers beyond what was possible under the common law in this reading, the HRA "unleashed" the Lords from the shackles previously imposed by parliamentary supremacy and the separation of powers. Such an explanation is plausible if we think that, already before the HRA, the courts were intent on strengthening their review powers; and the above-mentioned efforts at developing a jurisprudence of common law rights certainly support this view. ${ }^{143}$ Yet this explanation also raises problems. First, it is not entirely clear that British courts were indeed so keen on extending their powers of judicial review; otherwise, they might not have closed the door to ECHR arguments as tightly as they did in their 1991 Brind judgment. ${ }^{144}$ Secondly, and more importantly in our context, a desire for empowerment would not necessarily explain why the Lords should have tied themselves so firmly to Strasbourg jurisprudence - after all, they could also have extended their review powers by building on the common law like

\footnotetext{
138 See Court of Appeal, Judgment of 5 November 2002, Ghaidan v Godin-Mendoza, [2002] EWCA Civ 1533.

139 See only Lord Hope in House of Lords, Judgment of 26 June 2003, Aston Cantlow, [2003] UKHL 37, at [44-52]; I. Loveland, 'Does Homelessness Decision-Making Engage Article 6(1) of the European Convention on Human Rights?' (2003) European Human Rights Law Review, 176, 191-192.

140 See Lords Bingham, Slynn and Steyn, in R v Home Secretary ex parte Amin, n 130 above, at [32, 45, 5051]; and Lord Bingham in House of Lords, Judgment of 8 December 2005, A v Home Secretary (Torture Evidence), [2005] UKHL 71, at [51].

${ }^{141}$ See his speeches in House of Lords, Judgment of 11 March 2004, McKerr, [2004] UKHL 12,at [64-65]; Judgment of 14 November 2002, R v Lyons, [2002] UKHL 44, at [46]; Judgment of 9 May 2001, Alconbury, [2001] UKHL 23, at [76]. Instead of drawing on Strasbourg case-law, he often chooses to look to the tradition of rights under the common law; see only his speech in $A$ v Home Secretary (Belmarsh), $\mathrm{n}$ 132 above; for a careful analysis of his position there, see T. Poole, 'Harnessing the Power of the Past? Lord Hoffmann and the Belmarsh Detainees Case' (2005) 32 Journal of Law and Society 534.

${ }^{142}$ For a similar position, see Lord Hobhouse in Attorney General's Reference No 2 of 2001, n 131 above.

${ }^{143} \mathrm{I}$ am indebted to Martin Loughlin for drawing my attention to this point. See Hunt, n 127 above, chs. 5 and 6; Loughlin, n 136 above, for the developments, also on attempts at sharpening the scrutiny of administrative action to resemble more closely a proportionality test as required under the ECHR. See also J.A.G. Griffith, 'The Brave New World of Sir John Laws' (2000) 63 MLR 159, and his 'The Common Law and the Political Constitution' (2001) 117 Law Quarterly Review 42.

144 See House of Lords, Judgment of 7 February 1991, Brind v Home Secretary, [1991] 1 AC 696; and the detailed analysis in Hunt, n 127 above, ch. 6.
} 
the Court of Appeal, and this would have preserved them a greater degree of autonomy, too.

Yet perhaps the degree of loyalty to Strasbourg shown by the House of Lords can be explained in a similar way as that of the ECJ: as an attempt to defend its authority against challenge. This might be counterintuitive given that, as mentioned above, the Lords' authority, unlike that of the ECJ, had been established over centuries before even the ECtHR was created. Yet their role postHRA was largely new: they had been turned into a quasi-constitutional court with broad review powers over executive and legislative action, and this was in strong tension with previous assumptions about the role of courts under the British constitution. ${ }^{145}$ In this new role, the House of Lords enjoyed limited authority, and developing a municipal law of human rights might have appeared as too openly "creative": as a legislative rather than judicial function and therefore subject to greater challenge. Instead, relying closely on Strasbourg jurisprudence may have helped to maintain a more clearly judicial role, one of "applying" the law, and may have also appeared as merely executing a parliamentary mandate. This would correspond well with the observed general desire of courts to be perceived as nonpolitical actors, servants of the law but not autonomous creators. ${ }^{146}$ Tying its hand and limiting (or denying) its discretion might then have seemed to the House of Lords the safest option in the new - tempting but slightly uncomfortable position the HRA placed it in. ${ }^{147}$

\section{STRASBOURG'S ACCOMMODATION STRATEGIES}

The story of convergence between domestic courts and the ECtHR has so far been told from the perspective of the former and has highlighted factors that made domestic courts benefit from forging close links with Strasbourg. However, the gains from a cooperative relationship have usually been greater on the part of the ECtHR. From its inception, the Strasbourg organs were dependent on a positive stance by national authorities; with no enforcement tools at their disposal, compliance had to be essentially voluntary. If the Court and Commission wanted to become influential, they needed to establish, on the one hand, their authority as impartial and trustworthy interpreters of the Convention; on the other, they had to take care not to upset national authorities so much as to provoke a backlash. ${ }^{148}$ This posed a dilemma, as the image of impartiality could easily be undermined by

\footnotetext{
145 See, e.g., A. Tomkins, Public Law, Oxford: Oxford University Press, 2003, 102-125, also on earlier inroads into the principle of parliamentary supremacy in the EC context.

146 See A.-M. Burley \& W. Mattli, 'Europe before the Court: A Political Theory of Legal Integration' (1993) 47 International Organization 41, 72-73; W. Mattli \& A.-M. Slaughter, 'Revisiting the European Court of Justice' (1998) 52 International Organization 177, 196-198; Alter, n 98 above, 46.

147 The different approach of the Court of Appeal and Lord Hoffmann might then be due to a different assessment of how best to shield themselves from attack - they might think that referring to national traditions carries more weight with skeptics than foreign judgments. Poole, n 141 above, 554-555, 561, sees this concern at the basis of Lord Hoffmann's position.

148 See also Helfer \& Slaughter, n 98 above, 307-328.
} 
sensitivity for the concerns of particular member states, but Strasbourg managed to navigate between the two poles with great talent. ${ }^{149}$ In the early years, this involved strong elements of diplomacy: the EComHR often assumed a mediatory rather than adjudicatory role, much to the dismay of many legal scholars, but with the result of allaying member states' fears of an overly aggressive enforcement of human rights. ${ }^{150}$ Later, as the judicial function became increasingly settled, Strasbourg developed doctrinal tools to navigate thorny issues: the evolutive approach and the margin of appreciation.

Both of these tools are well-known; together, they allowed for an incremental expansion of the reach of the Convention, responsive to the pace of progress in member states, but in a doctrinal, not openly political framework. ${ }^{151}$ We have already seen a striking example for the evolutive approach in the stance of the ECtHR towards advocates-general; the shift from the 1970 Delcourt case to the 1991 Borgers case was justified precisely by the need to reflect the "evolution" of the requirements of a fair trial. ${ }^{152}$ This dynamism in interpreting the Convention has often been criticised ${ }^{153}$, and understandably so, as there are hardly any methodological guidelines for how it is to be applied ${ }^{154}$ - after all, it is a tool of judicial politics that grants the Court flexibility in responding to circumstances and opportunities. The critique has been even greater with respect to the second tool, the margin-of-appreciation doctrine that limits the stringency of the proportionality test by deferring to the judgment of member states. The extent of this margin depends on a number of criteria; the Court usually emphasises the degree of consensus among member states, and on particularly contentious issues it has indeed stepped back to await the crystallization of a common European approach and has sought to respond to political movement within the member states concerned. ${ }^{155}$ However, the application of this doctrine has been open to the charge of great casuistry, reinforcing the already significant context-specificity

\footnotetext{
149 See Helfer \& Slaughter, n 98 above, 313-314. Some evidence suggests that the Court has in fact been more lenient on powerful states than on others; E. Voeten, 'The Impartiality of International Judges: Evidence from the European Court of Human Rights', 18, http://papers.ssrn.com/sol3/ papers.cfm?abstract_id $=705363$.

150 See F.-J. Hutter, 'Die Erfolgsgeschichte der EMRK - Vom Nachkrieg zur europäischen Friedensordnung', in Grewe \& Gusy, n 15 above, 36-54, at 46-48.

151 See P. van Dijk \& G.J.H. van Hoof, Theory and Practice of the European Convention on Human Rights (The Hague: Kluwer Law International, 3rd. ed, 1998) 82-95; A. Mowbray, 'The Creativity of the European Court of Human Rights' (2005) 5 Human Rights Law Review 57.

152 ECtHR, Judgment of 30 October 1991, Borgers v Belgium, at [24].

153 See, e.g., F. Matscher, 'Methods of Interpretation of the Convention', in R. St. J. Macdonald, F. Matscher \& H. Petzold (eds.), The European System for the Protection of Human Rights (Dordrecht: Martinus Nijhoff Publishers, 1993) 63-81, at 69-70.

154 This is conceded even by supporters of the approach; see, e.g., Mowbray, n 151 above, 71.

155 See H.C. Yourow, The Margin of Appreciation Doctrine in the Dynamics of European Human Rights Jurisprudence (The Hague: Kluwer Law International, 1996) 193-196; Y. Arai-Takahashi, The Margin of Appreciation Doctrine and the Principle of Proportionality in the Jurisprudence of the ECHR (Antwerpen: Intersentia, 2002) 203-204; van Dijk \& van Hoof, n 151 above, 87-91, also on various other factors influencing the extent of the margin. See also the example of transsexualism discussed below.
} 
of the proportionality test and often preventing generalisable inferences for future cases. ${ }^{156}$

The critique of these tools by scholars who regard coherence and legal certainty as central elements of the rule of law $^{157}$ is thus understandable, but the value of the resulting flexibility for a court that is in the process of establishing its authority can hardly be overestimated. ${ }^{158}$ It helps to avoid clashes with member states and their courts while keeping alive the promise of a more effective human rights protection in the future, thereby also alerting national authorities to the risk that particular policies might one day be regarded as violations. The story of the treatment of transsexuals in Britain is a good illustration of this point: Strasbourg was lenient in 1986, emphasising the lack of consensus in Europe and the resulting broad margin of appreciation ${ }^{159}$, but tightened its jurisprudence considerably over the next decade, warning Britain that it had to keep the situation under review. ${ }^{160}$ When the political response was muted and even provoked explicit criticism by the Court of Appeal, the ECtHR eventually came to find a violation of the Convention on the basis of a much-reduced margin of appreciation. ${ }^{161}$ Here, the ECtHR, rather than merely stating the law, was administering change in a dialogue with national institutions that benefited much from the flexibility of its doctrinal tools.

However, these tools have not always led to an extension of human rights protection; sometimes they have also allowed for retreat in reaction to national concerns. We have already seen above how Strasbourg modified and limited its jurisprudence on the role of advocates-general when faced with the opposition of the Conseil d'Etat.162 Another example is the shift in the ECtHR's stance towards the implementation of the Convention in domestic law. The Convention is not explicit about a need for incorporation, but in the 1970s, the Court described such incorporation as a "particularly faithful reflection of the drafters' intention". ${ }^{163}$ However, faced with the continuing resistance of a number of states - especially the UK and the Scandinavian countries - it began to limit itself to stating that there was no preferred way of achieving compliance with the Convention and that incorporation was not legally required. ${ }^{164}$ It became again slightly more demanding

\footnotetext{
156 See J.A. Brauch, 'The Margin of Appreciation and the Jurisprudence of the European Court of Human Rights' (2004) 11 Columbia Journal of European Law 113, 125; Greer, n 4 above, 223, 323; also van Dijk \& van Hoof, n 151 above, 91-95.

157 See, e.g., M.R. Hutchinson, 'The Margin of Appreciation Doctrine in the European Court of Human Rights' (1999) 48 ICLQ 638; Brauch, n 156 above.

158 See R. St. J. Macdonald, 'The Margin of Appreciation', in Macdonald, Matscher \& Petzold, n 153 above, 83-124, at 122-124; van Dijk \& van Hoof, n 151 above, 95; Helfer \& Slaughter, n 98 above, 1997, 316-317; R. Goodman \& D. Jinks, 'How to Influence States: Socialization and International Human Rights Law' (2004) 54 Duke Law Journal 621, 702.

${ }^{159}$ ECtHR, Judgment of 17 October 1986, Rees v United Kingdom, especially at [37].

160 ECtHR, Judgment of 27 September 1990, Cossey v United Kingdom, at [42]; Judgment of 30 July 1998 ,

Sheffield and Horsham v United Kingdom, at [60]. See also Arai-Takahashi 2002, 72-74.

161 ECtHR, Judgment of 11 July 2002, Christine Goodwin v United Kingdom.

162 See text at $\mathrm{n} 74-84$ above.

163 ECtHR, Judgment of 18 January 1978, Ireland v United Kingdom, at [239].

164 See, e.g., ECtHR, Judgment of 21 February 1986, James and others v United Kingdom, at [84].
} 
in its 1991 Vermeire judgment when it censured Belgium for its failure to amend legislation on illegitimate children following the Marckx judgment twelve years earlier. ${ }^{165}$ Yet its general approach remained cautious until the early 2000s when the negotiations on Additional Protocol No. 14 gave questions of execution greater political weight. 166 Thus, in 2004, the Court returned to a more determined language, holding that states were obliged to modify their domestic law if this was necessary to end violations of the Convention and fully comply with ECtHR judgments. ${ }^{167}$ And following an invitation by the Council of Europe's Committee of Ministers, it also began to identify systemic problems in member states that required a broader legislative response. ${ }^{168}$ This is still far from its initial approach and certainly does not reflect a general duty to incorporate the Convention, but it shows the Court's particular sensitivity to the political process and its readiness to react to resistance as well as encouragement. After all, the process of accommodation in the ECHR framework is not a one-way street leading to ever greater authority of Strasbourg; instead, it is a mutual process in which signals from political actors, including courts, feed back into ECtHR jurisprudence.

\section{PLURALISM'S APPEAL}

As we have seen, in the day-to-day operation of the European human rights regime, the pluralist structure of European human rights law has mostly produced not conflict and friction but harmony and convergence. The different courts involved have not made aggressive use of their discretionary space; instead, they have sought to accommodate each other in a cooperative relationship. Yet has this happened despite, or perhaps because of, the pluralist structure?

\section{The Success of the European Human Rights Regime}

On one level, this success has little to do with the pluralist character of the regime, but is the result of favourable political circumstances. The ECHR benefited much from the geopolitical environment: it allowed Western European states to demonstrate their commitment to human rights in the face of the Soviet challenge. ${ }^{169}$ Within Europe, the absence of concentrated power facilitated the

\footnotetext{
165 ECtHR, Judgment of 29 November 1991, Vermeire v Belgium, at [23-28].

166 See Greer, n 4 above, 159-165; V. Colandrea, 'On the Power of the European Court of Human Rights to Order Specific Non-monetary Measures: Some Remarks in Light of the Assanidze, Broniowski and Sejdovic Cases' (2007) 7 Human Rights Law Review 396.

167 ECtHR, Judgment of 17 February 2004, Maestri v Italy, at [47]; Judgment of 8 April 2004, Assanidze v Georgia, at [198]; see also the Recommendation $\operatorname{Rec}(2004) 6$ of the Committee of Ministers to member states on the improvement of domestic remedies, of 12 May 2004, .

168 ECtHR, Judgment of 22 June 2004, Broniowski v Poland, at [189-194]; Resolution Res(2004)3 of the Committee of Ministers on judgments revealing an underlying systemic problem, of 12 May 2004.

169 See A.W.B. Simpson, 'Britain and the European Convention' (2001) 34 Cornell International Law Journal 523, 542-54; D. Nicol, 'Original Intent and the European Convention on Human Rights' Public Law
} 
operation of the Convention mechanism: none of the most powerful member states could expect to see its preferences fully reflected in the Convention; the UK, France and Germany all had to accept that ECtHR jurisprudence drew on a range of traditions. ${ }^{170}$ And for most of the life of the Convention, its members (then mainly Western European) shared relatively homogeneous political systems and cultural values. ${ }^{171}$ In this situation, violations were usually not terribly grave, and the findings of violations were not particularly concentrated; though some countries lost more often than others in Strasbourg, none of them was a clear outlier that could have challenged the system or would have made resistance a routine position. ${ }^{172}$ Beyond that, member states had a sufficient stake in a working system to accept occasional defeat. Their interests in it were quite varied, ranging from bolstering the human rights credentials of the West, spreading one's own values, protecting human rights achievements from potential domestic challenge and signalling a commitment to liberal democracy so as to enter (or maintain membership in) the Western club. ${ }^{173}$ For most countries, and most of the time, these benefits of membership outweighed the costs, and gradually reputational concerns also came to solidify the regime.

The formal structure of the regime had little impact on all this, except of course the costs for member states - the scope of the obligations under the Convention and the likelihood of being found in violation. The initial design of the ECHR kept these costs low: the Convention reflected a minimal consensus, and many member states believed it did not require changes to their laws and institutions. ${ }^{174}$ As we have seen, the ECtHR has been careful not to raise these costs too suddenly: while giving Convention rights increasing bite over time, it did so in an incremental fashion that never departed too much from the level of rights protection already consolidated in member states. The evolutionary approach to interpretation and the related margin-of-appreciation doctrine - central political tools in a pluralist order ${ }^{175}$ - thus quite likely helped stabilise the European human rights regime to a significant extent. ${ }^{176}$ Most observers recognise that, even if they

2005, 152-172; also A. Moravcsik, 'The Origins of Human Rights Regimes: Democratic Delegation in Postwar Europe' (2000) 54 International Organization 217, 242.

$170 \mathrm{On}$ the problems of superpower status for participation in international human rights regimes, see A. Moravcsik, 'Why Is U.S. Human Rights Policy So Unilateralist?', in S. Patrick \& S. Forman (eds.), Multilateralism and U.S. Foreign Policy (Boulder: Lynne Rienner, 2002) 345-376, at 348-350.

171 On the importance of this point, see R. Bernhardt, 'Commentary: The European System' (1987) 2 Connecticut Journal of International Law 299, 299-300; E.A. Posner \& J.C. Yoo, Judicial Independence in International Tribunals' (2005) 93 California Law Review 1, 55; but see also the more cautious assessment in Helfer \& Slaughter, n 98 above, 335-336.

172 When this might have happened to Greece, Greece left the Convention system; see Greer, $\mathrm{n} 4$ above, 26. Turkey, the other systematic outlier, had a particular interest in showing a commitment to human rights.

173 See Simpson, 'Britain and...', n 169 above; Moravcsik, n 169 above; Gusy, n 15 above; also E. Voeten, 'The Politics of International Judicial Appointments: Evidence from the European Court of Human Rights', International Organization, forthcoming.

${ }^{174}$ Hutter, n 150 above, 42-45.

175 See Delmas-Marty, $\mathrm{n} 7$ above, 71-74; and text at n 151-161 above.

176 See Helfer \& Slaughter, n 98 above, 314-317; Goodman \& Jinks, n 158 above, 702. See also Hutter, n 150 above, 46-48, on the early work of the Commission. 
have constitutionalist sympathies and are skeptical of the political nature of these tools. ${ }^{177}$

However, we might find a broader effect of pluralism when we return to the focus of previous sections: the interaction of courts. The courts have played a crucial role in the development of the overall regime, both on the European level where the Strasbourg Court has stimulated large-scale change, and on the domestic level where courts have anchored the Convention in domestic societies. Studies of the influence of international human rights norms generally attach much weight to "institutionalisation and habitualisation" on the domestic level178; and courts are widely regarded as central to the microprocesses of implementation and compliance in transnational dispute resolution. ${ }^{179}$ Because of the strength of the rule of law in most member states of the Convention, non-compliance with domestic court decisions comes at a high cost for political actors; if a domestic court thus gives effect to ECtHR judgments, this often guarantees general compliance. ${ }^{180}$

\section{Court Attitudes}

How has the pluralist structure of the European human rights regime then influenced the likelihood of cooperation among the courts? If court action were determined primarily by formal rules, we would expect domestic courts to follow Strasbourg decisions more readily in a constitutionalist order in which European norms enjoy primacy over domestic ones. But already our limited survey of judicial dialogues has shown that the formal setting has only played a limited role. In France, despite the ECHR's supremacy over domestic statutes, courts have been reluctant to exercise review powers; on the other hand, the ECJ has given effect to ECtHR jurisprudence despite the absence of a formal basis. This corresponds with the observation that the incorporation of the Convention is not a dominant factor for compliance. ${ }^{181}$ Of course, this does not imply that form is entirely inconsequential: the example of the UK shows well that the absence of a formal mandate to apply the ECHR made the courts reluctant to use it; only after the HRA did they feel authorised to so. Yet, while form certainly played a role in

\footnotetext{
177 See Greer, n 4 above, 214; van Dijk \& van Hoof, n 151 above, 95.

${ }^{178}$ T. Risse \& S.C. Ropp, 'International human rights norms and domestic change: conclusions', in T. Risse, S.C. Ropp \& K. Sikkink (eds.), The Power of Human Rights: International Norms and Domestic Change (Cambridge: Cambridge University Press, 1999) 234-278, at 249-250, 277.

179 R.O. Keohane, A. Moravcsik \& A.-M. Slaughter, 'Legalized Dispute Resolution: Interstate and 'Transnational' (2000) 54 International Organization 457, 478.

${ }^{180}$ Greer, $\mathrm{n} 4$ above, 279.

181 See Lambert, n 7 above, 209, 378-379; Queralt Jiménez, n 24 above, 217; Greer, n 4 above, 83-85 (though with methodological problems); and the account in Helfer \& Slaughter, n 98 above, 306-307.
} 
setting the boundaries of court action, it was hardly determinative of it ${ }^{182}-\mathrm{a}$ finding that is consistent with studies of other higher courts. ${ }^{183}$

Which other factors are then likely to have influenced court action vis-à-vis Strasbourg? On the basis of our observations above and of analyses of other courts $^{184}$, one can hypothesise at least five central ones: substance; institutional role; persuasion; authority; and autonomy. ${ }^{185}$

Substance. "Substance" denotes the degree of congruence of a substantive position with judges' substantive attitudes; the assumption is that judges will have a preference for interpretive outcomes that correspond with their political views and value judgments. This idea has dominated studies of the US Supreme Court ${ }^{186}$; it is, however, hard to operationalise in our context as ECtHR jurisprudence is difficult to locate clearly on a left-right spectrum ${ }^{187}$ and systematic studies of the correlation between the political views of judges on domestic courts and their attitude towards Strasbourg do not exist. Yet in one respect, this category appears as useful here: one can assume that domestic judges will often be inclined to see a solution enshrined in their own law as superior to one coming from a foreign source, in part simply because they are used to applying their own law. This seems to be reflected, for example, in the Bundesverfassungsgericht's quiet acceptance of Strasbourg jurisprudence over a long period; until very recently, Strasbourg seemed to be generally in line with German interpretations of fundamental rights and thus did not present a serious threat.

Institutional commitments. The second factor, "institutional commitments", refers to principled positions of judges not on the substantive outcome of a decision, but on the institutional place of their court and, more broadly, the right locus of decision-making. Judges have generally been found to be (at least partly) guided by their role orientations ${ }^{188}$, and we can see this reflected, for instance, in the reluctance of French and British courts to extend their review powers despite formal opportunities to do so. This fact is at least partly explicable on the basis of the entrenched limitations on their role in the French and British political orders, the strength of parliamentary supremacy and ideas about the ultimate supremacy of national over European law. ${ }^{189}$

Persuasion. The third factor still refers to ideas, though not so much to the resonance of international decision-making with existing ideas of domestic courts but to its capacity to change those ideas, its persuasive power. At least in the self-

\footnotetext{
182 See also J. Polakiewicz, Die Verpflichtungen der Staaten aus den Urteilen des Europäischen Gerichtshofs für Menschenrechte (Berlin, Heidelberg: Springer-Verlag, 1993) 331.

183 See J.L. Gibson, 'Judicial Institutions', in R.A.W. Rhodes, S.A. Binder \& B.A. Rockman (eds.), The Oxford Handbook of Political Institutions (Oxford: Oxford University Press, 2006) 515-534, at 518; in the EC law context, Mattli \& Slaughter, n 146 above, at 203.

184 A useful survey can be found in Gibson, n 183 above.

185 These are not meant as exhaustive, but should provide a useful prism to structure the discussion.

186 See J.A. Segal \& H.J. Spaeth, The Supreme Court and the Attitudinal Model (Cambridge: Cambridge University Press, 1993).

${ }^{187}$ For an attempt in this direction, see Voeten, n 173 above.

188 See Gibson, n 183 above, 519-520.

189 See Alter, n 98 above, ch. 4, on French courts in the EC context.
} 
description of judges, persuasion through argument is the central mode of evolution in jurisprudence; and its force will hinge on the quality of the argument itself, the cogency of legal reasoning, but also on the standing and impartiality of the individual or body making the argument. Much of the success of the ECJ has been attributed to its appearance of autonomy from politics as well as its formalist style of reasoning ${ }^{190}$, and in the generally formalist legal culture of Europe, this factor is likely to be influential for the impact of the ECtHR as well. ${ }^{191}$

Authority. Among the more strategic factors, "authority" refers to the interest of courts in maintaining or strengthening their authority vis-à-vis other actors. ${ }^{192}$ This factor has often been regarded as central in the mobilisation of domestic (lower) courts for the implementation of European Communities law ${ }^{193}$, and in my short discussions of courts' attitudes above, it has also taken a prominent place. In all of the cases discussed, enhancing the courts' authority has had a plausible place, most obviously for the Spanish Tribunal Constitucional in the transition from dictatorship, and for the ECJ in coping with challenges by domestic courts. But as the French case shows - and a similar finding applies to French courts in the EU context $1^{194}$ - courts are not always keen to enhance their influence, even if the formal setting allows for it; convictions about their rightful place or considerations of legitimacy might prevent them from doing so.

Autonomy. "Autonomy" is another factor with obvious influence in the EU context - unlike lower courts, the highest national courts were eager to maintain their position at the top of the judicial hierarchy, even if this meant foregoing possibilities of stronger review of political action. ${ }^{195}$ The importance of this factor is also suggested by the fact that actors usually embrace change more easily as a result of their own choice rather than external pressure. ${ }^{196}$ And autonomy certainly seems at play in our context, particularly clearly in courts' efforts to formally retain the last word on whether to follow Strasbourg decisions or not - a point all the courts studied here have insisted upon.

\section{The Impact of Pluralism}

How then has the pluralist structure affected those different factors in the context of the ECHR? As mentioned above, compared to constitutionalism, pluralism appears as the weaker option with respect to form, but then form seems to have

\footnotetext{
190 J.H.H. Weiler, 'A Quiet Revolution: The European Court of Justice and its Interlocutors' (1994) 26 Comparative Political Studies 510, 520-521.

${ }^{191}$ See Helfer \& Slaughter, n 98 above, 312-314, 318-323, 326-328.

192 Mattli \& Slaughter, n 146 above, 190-194; and Gibson, n 183 above, 521-530, usefully discuss different aspects of this interest.

${ }^{193}$ Lower courts were empowered by the opportunities to exercise review offered by EC law; see J.H.H. Weiler, 'The Transformation of Europe' (1991) 100 Yale Law Journal 2403, 2426; Burley \& Mattli, n 146 above, 63-64; in the same vein, but with more nuanced assessments, see Mattli \& Slaughter, n 146 above, 190; Alter, n 98 above, 45-52.

${ }^{194}$ See Alter, n 98 above, 141-142.

195 ibid, 48-49.

${ }^{196}$ Goodman \& Jinks, n 158 above, 698.
} 
played only a limited role. Likewise, with respect to authority, pluralism is ambivalent: by making plain the element of discretion and choice of domestic courts, it has prevented them from hiding entirely behind a Strasbourg decision. But as we have seen in the discussion of the UK, if the domestic court has a stronger standing than the international body, it might actually benefit from the dissociation that comes with pluralism.

Similarly ambivalent is the impact of the pluralist structure on persuasion. The incrementalist element in pluralism helps tune supranational demands to what domestic courts seem ready to embrace and limits excessive requirements that would provoke a backlash. On the other hand, the stronger political component of pluralism might make persuasion more difficult: it can make an international court appear as a political body and thereby taint its legal arguments. Escaping such appearances while remaining politically sensitive means walking a precariously fine line.

On other counts, though, pluralism seems to present distinct advantages. This is clear with respect to substance: the incrementalist, political approach that the pluralist structure has been ready to embrace has helped limit the gap between Strasbourg decisions and domestic law at any given time and is thus likely to have limited resistance from those judges who believe "their" law contained the right solution.

Advantages are also obvious with respect to autonomy: the pluralist order has allowed domestic courts to insist on their final authority, and they have done so in all cases studied. Without the possibility of such insistence (which a constitutionalist approach would imply), pragmatic accommodation from all sides would have been considerably less likely. In a similar vein, advantages accrue as regards institutional commitment. Domestic judges, socialized in a national constitutional setting, will usually have internalised a vision of the domestic constitution as the final point of reference, and of domestic decision-makers as having the final word. A pluralist order threatens these views less than a constitutionalist one: it accepts that domestic actors - just like international bodies - stick to their views on supremacy and rather than deciding them as a matter of principle, seeks to work around them. In that sense, it presents a more limited challenge not only to the autonomy of domestic courts, but also to their particular institutional commitments.

In sum, then, pluralism's contribution to the stability of the European human rights regime seems significant. We might not be able to quantify the role of the different factors presented here or even determine their relative weight for the different courts involved. But the discussion has shown that on a number of issues domestic courts care about, the incrementalism and openness of pluralism might well have worked to the benefit of the overall regime. Leaving the fundamental structures open may have allowed for a gentler, and ultimately more successful, way of engaging a variety of actors in the creation of a postnational order - at least in conditions that, as in the European human rights regime, have been favourable enough to allow courts and their dialogues a central role in that process. 


\section{CONCLUSION}

The constitutionalist narrative of the evolution of the European human rights regime, so powerfully manifested in the reactions to the Görgülü judgment, has come to appear more as a story of hope than a reflection of reality. While domestic and European human rights law have indeed become increasingly linked and Strasbourg decisions are regularly followed by national courts, this does not indicate the emergence of a unified, hierarchically ordered system along constitutionalist lines. Instead, as we have seen throughout our case studies, domestic courts insist on the ultimate supremacy of their own legal order over European human rights law, and they have thus created a zone of discretion in deciding whether or not to respect a judgment of the ECtHR, allowing them to negotiate with Strasbourg on issues they feel particularly strongly about. Yet in spite of this divergence on fundamentals, the interplay between the different levels of law has been remarkably harmonious and stable. There have hardly been open clashes; instead, mutual accommodation and convergence have been the norm, facilitated by the flexible and responsive strategies of the courts involved, and especially of the ECtHR itself.

This is initially surprising as pluralism, unlike constitutionalism, is often associated with disorder and the risk of friction. Yet as we have seen, the pluralist structure of the European human rights regime seems to have created favourable circumstances for the generally harmonious dialogue between domestic and European courts. In particular, the strong incrementalism it allows for has limited the extent of the demand for adaptation on the part of national courts and is thus likely to have prevented overreach by Strasbourg and consequently the risk of a backlash. Likewise, pluralism has catered to national courts' desire for maintaining their autonomy; it has allowed them to insist on their superior status in principle and in the shadow of this status to make gradual, pragmatic concessions. In this way, by leaving issues of principle open, the pluralist structure has limited the antagonism between the different institutions involved and has helped them move to a stage where they could mutually benefit from a cooperative relationship.

In those respects, then, the experience of the European human rights regime points to the appeal of pluralist forms of order in postnational constellations more generally. In situations where contestation is strong and authorities are not firmly settled, a pluralist order can contribute to the transformation of a regime over time and allow for responsiveness to different actors according to their changing political weight and public legitimacy. By leaving questions of fundamental norms and ultimate authority undecided, pluralism might give postnational law the flexibility it needs in order to deal with principled contestation - contestation might be easier to circumnavigate than in a constitutional order built on the ideal that these questions are settled in one way or another.

This does not suggest easy solutions for other areas of postnational governance: as we have seen, the political environment in which the European 
human rights regime operates are particularly favourable, and its experiences are therefore not easily transferable. Yet the benefits of a pluralist order in this context indicate that we should not too readily accept calls for a postnational constitutionalism with a comprehensive rule of law in an effort to tame unruly politics. Given the circumstances of postnational governance, a pluralist order that allows space for politics in the determination of fundamental issues might well be more appropriate. ${ }^{197}$

197 For an initial exploration of broader normative issues of pluralism in the framework of global governance, see Krisch, n 13 above, 263-277. 